NBER WORKING PAPER SERIES

\title{
THE VALUE OF CLIMATE AMENITIES: EVIDENCE FROM US MIGRATION DECISIONS
}

\author{
Paramita Sinha \\ Maureen L. Cropper \\ Working Paper 18756 \\ http://www.nber.org/papers/w18756
NATIONAL BUREAU OF ECONOMIC RESEARCH
1050 Massachusetts Avenue
Cambridge, MA 02138
February 2013

\begin{abstract}
We would like to thank the U.S. Environmental Protection Agency, Resources for the Future, and RTI International for funding and Wolfram Schlenker for generously providing data from the Hadley III model. We would like to thank Sara Casey and Martha Caulkins for excellent research assistance and Jamie Cajka and Kibri Everett for providing GIS support. We would also like to thank participants at seminars at the Camp Resources, National Center for Environmental Economics, Resources for the Future, Columbia University, the Annual Social Sciences Association meetings, and the Third World Congress of Environmental and Resource Economists. The views expressed herein are those of the authors and do not necessarily reflect the views of the National Bureau of Economic Research.
\end{abstract}

At least one co-author has disclosed a financial relationship of potential relevance for this research. Further information is available online at http://www.nber.org/papers/w18756.ack

NBER working papers are circulated for discussion and comment purposes. They have not been peerreviewed or been subject to the review by the NBER Board of Directors that accompanies official NBER publications.

(C) 2013 by Paramita Sinha and Maureen L. Cropper. All rights reserved. Short sections of text, not to exceed two paragraphs, may be quoted without explicit permission provided that full credit, including (c) notice, is given to the source. 
The Value of Climate Amenities: Evidence from US Migration Decisions

Paramita Sinha and Maureen L. Cropper

NBER Working Paper No. 18756

February 2013

JEL No. Q5,Q51

\begin{abstract}
$\underline{\text { ABSTRACT }}$
We value climate amenities by estimating a discrete location choice model for households that changed metropolitan statistical areas (MSAs) between 1995 and 2000. The utility of each MSA depends on location-specific amenities, earnings opportunities, housing costs, and the cost of moving to the MSA from the household's 1995 location. We use the estimated trade-off between wages and climate amenities to value changes in mean winter and summer temperatures. At median temperatures for 1970 to 2000, a $1^{\circ} \mathrm{F}$ increase in winter temperature is worth less than a $1^{\circ}$ decrease in summer temperature; however, the reverse is true at winter temperatures below $25^{\circ} \mathrm{F}$. These results imply an average welfare loss of 2.7 percent of household income in 2020 to 2050 under the B1 (climate-friendly) scenario from the special report on emissions scenarios (Intergovernmental Panel on Climate Change 2000), although some cities in the Northeast and Midwest benefit. Under the A2 (more extreme) scenario, households in 25 of 26 cities suffer an average welfare loss equal to 5 percent of income.
\end{abstract}

Paramita Sinha

Research Triangle Institute

701 13th Street, NW

Suite 750

Washington, DC 20005-3967

psinha@rti.org

Maureen L. Cropper

Department of Economics

University of Maryland

College Park, MD 20742

and NBER

cropper@econ.umd.edu 


\section{Contents}

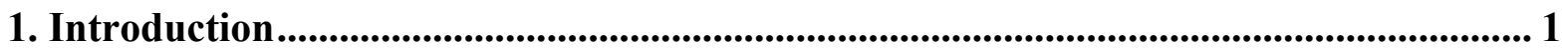

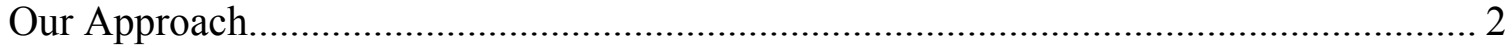

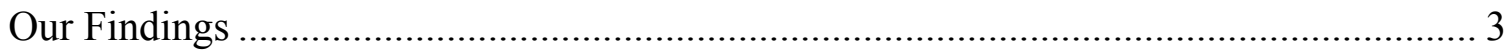

2. Household Residential Location Model ....................................................................... 4

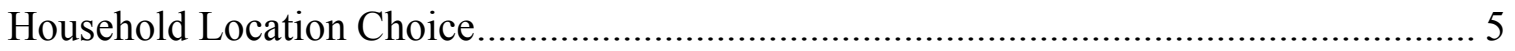

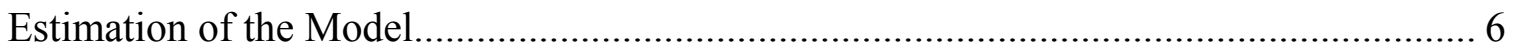

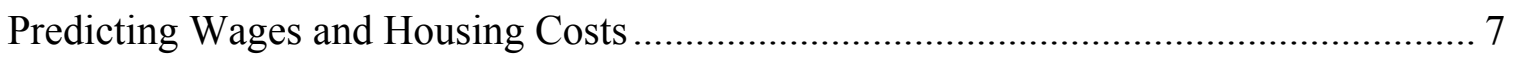

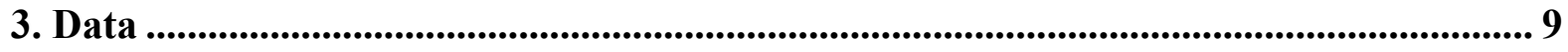

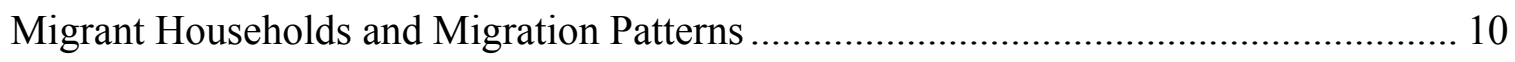

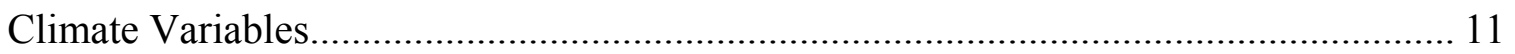

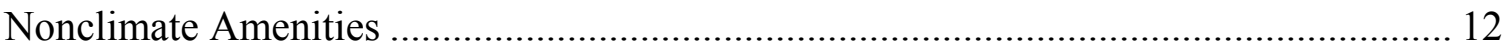

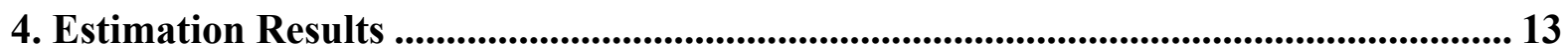

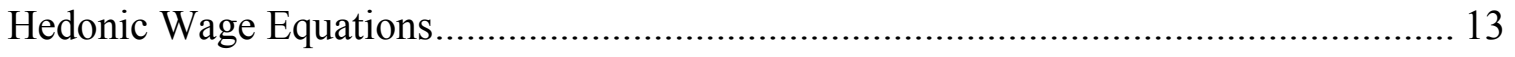

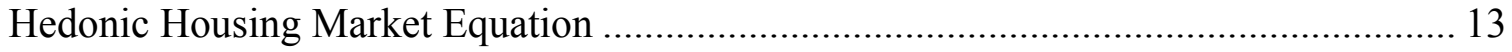

Results from the First Stage of the Migration Model .................................................. 14

Results from the Second Stage of the Migration Model............................................... 15

MWTP for Climate Amenities........................................................................... 17

5. WTP for Temperature Changes .............................................................................................. 18

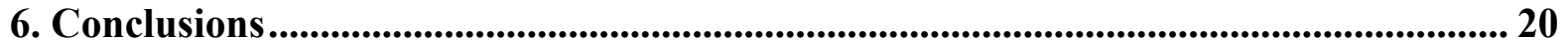

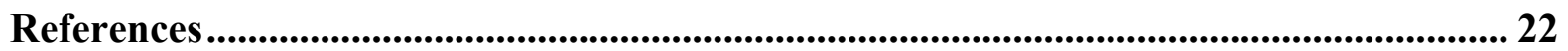

Figures and Tables............................................................................................................................... 24 


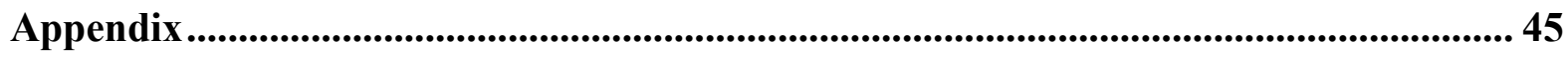




\title{
The Value of Climate Amenities: Evidence from US Migration Decisions
}

\author{
Paramita Sinha and Maureen L. Cropper*
}

\section{Introduction}

The amenity value of climate — what people are willing to pay to experience warmer winters or to avoid hotter summers - is an important component of the benefits of greenhouse gas mitigation policies. Yet the literature contains few recent estimates of the value of climate amenities for the United States. ${ }^{1}$ This paper helps fill this gap by estimating a discrete location choice model in which a household's choice of the city in which to live depends on climate amenities as well as earnings, housing costs, and other location-specific amenities. We use the model to estimate household willingness to pay (WTP) for changes in mean winter and summer temperature and use these values to assess the welfare effects of temperature changes in cities throughout the United States.

Traditionally, economists have used hedonic wage and property value functions to value climate amenities (Cragg and Kahn 1999; Gyourko and Tracy 1991; Blomquist et al. 1988; Smith 1983). In a world in which households can migrate costlessly across cities, locationspecific amenities should be capitalized into wages and property values. In equilibrium, each household will select a city (i.e., a vector of amenities) so that the marginal cost of obtaining each amenity, measured in terms of wages and housing costs, just equals the value it places on the amenity (Roback 1982). ${ }^{2}$

The continuous hedonic approach, however, assumes that moving is costless. ${ }^{3}$ As Bayer et al. (2009) have pointed out, moving costs imply that a household's marginal WTP (MWTP) need not equal the weighted sum of the slopes of the hedonic wage and property value equations.

\footnotetext{
* Paramita Sinha, RTI International; Maureen Cropper, University of Maryland and Resources for the Future, cropper@rff.org.

${ }^{1}$ A notable exception is Albouy et al. (2011).

${ }^{2}$ Formally, marginal WTP for an amenity must equal the sum of the slope of the hedonic wage function with respect to the amenity plus the slope of the hedonic property value function evaluated at the chosen amenity vector (Roback 1982).

${ }^{3}$ It also assumes, in most specifications, national labor and housing markets.
} 


\section{Sinha and Cropper}

An alternative approach, which does allow for moving costs, is to estimate the parameters of a household's utility function directly using a discrete model of location choice (Bayer et al. 2004; Bayer and Timmins 2007; Klaiber and Phaneuf 2010).

\section{Our Approach}

In this paper, we value climate amenities by estimating a model of residential location choice for households that changed metropolitan statistical areas (MSAs) between 1995 and 2000. We model the decision of migrants as a choice among MSAs based on potential earnings, housing costs, moving costs, climate amenities, and other location-specific amenities. The model is estimated in two stages (Berry et al. 1995; Bayer et al. 2009; Klaiber and Phaneuf 2010). In the first stage, MSA-specific constants are estimated together with other utility function parameters to explain the location choices of migrants. In the second stage, the MSA-specific constants are regressed on amenities that vary by MSA to estimate the average utility attached to these amenities. This procedure allows us to identify the parameters of households' indirect utility functions and, thus, to estimate the welfare effects of changes in climate variables.

In our location choice model, the marginal value of an amenity is the rate of substitution between the wage and the amenity in question. To estimate the coefficient on the wage, households must compare differences in wages across locations. This implies that the model is not suitable for estimating the preferences of retirees or households with no wage income. It is also the case that, conditional on moving costs, households must in fact be maximizing utility: if households do not compare other cities with their point of origin, the discrete choice model will not recover preferences for amenities.

We focus on households that have moved recently ("movers") on the grounds that they are more likely to be in equilibrium than households that have not moved ("stayers"). ${ }^{4}$ Although it is impossible to formally test this proposition, location choice models that we have estimated using movers and stayers suggest that stayers place much less weight on wages than movers do, suggesting that they may not be considering all relevant options in determining their current

\footnotetext{
${ }^{4}$ We also focus on households whose heads are prime aged (between 26 and 55 years old); prime-aged heads have greater labor force attachment than older workers (see Table 1).
} 


\section{Sinha and Cropper}

locations (Sinha 2008). ${ }^{5}$ We therefore measure the preferences of households that have recently moved, acknowledging that their preferences may differ from those of stayers. We do, however, measure the impact of household characteristics - specifically, the impact of household size and the age of the household head-on WTP for locational amenities.

Our paper builds on the work of Cragg and Kahn (1997), who were the first to use a discrete choice approach to value climate amenities. ${ }^{6}$ We extend their work, following Bayer et al. (2009) by including moving costs and modeling choices across MSAs. Unlike Bayer et al., however, we cannot use multiple cross-sections to difference out unobserved amenities across cities. Historical data indicate that climate changes slowly, forcing us to rely on a single crosssection of data rather than data over consecutive decades. ${ }^{7} \mathrm{We}$ attempt to allay concerns about omitted variable bias by controlling for a wide variety of location-specific amenities other than temperature, especially those that are correlated with temperature.

\section{Our Findings}

Our results indicate that households are willing to pay to avoid cold winter temperatures and hot summer temperatures. The important question for assessing the impacts of climate change is the relative weight that households place on increases in summer versus winter temperature. Evaluated at the means of our data, MWTP to lower summer temperature by $1^{\circ} \mathrm{F}$ is greater than MWTP for a $1^{\circ}$ increase in winter temperature. Moreover, MWTP for higher winter temperature decreases as temperature increases. The disamenity of hotter summers appears to decrease slightly with mean summer temperature, but, because mean summer temperature varies less than mean winter temperature, this effect is estimated less precisely than for winter temperature.

Our results also suggest that the value attached to climate amenities varies with the age of the household head and with household size: households whose heads are between 46 and 55 years old place more value on climate amenities than households whose heads are between 26

\footnotetext{
${ }^{5}$ Bayer et al. (2009) use data on movers and stayers but limit their sample to households with heads $\leq 35$ years of age, who are more mobile than the rest of the population.

${ }^{6}$ Cragg and Khan (1997) value climate amenities by estimating a model of the choice of state in which to live for households that moved between 1985 and 1990.

${ }^{7}$ This is also true of the literature that examines the impact of climate on agriculture (Schlenker and Roberts 2009).
} 


\section{Sinha and Cropper}

and 35 years old, a result that agrees with Cragg and Kahn (1997). Smaller households place a lower value on amenities than larger households, although this effect is not as pronounced.

We use these estimates to value changes in mean summer and winter temperature over the period 2020 to 2050 for 26 US cities. The Hadley model projects that, under the B1 scenario from the special report on emissions scenarios (SRES), 8 mean summer temperature will increase, on average, by $3.3^{\circ} \mathrm{F}$ in these cities and mean winter temperature by $3.3^{\circ} \mathrm{F}$. Cities in the northeastern United States will experience larger increases in winter temperature than in summer temperature, although the reverse is true for cities in the South and Southwest. We find that average WTP for temperature changes projected to occur in the Northeast is positive, ranging from 1.0 to 3.5 percent of income. The disamenity value of climate changes in Dallas - a city that is projected to experience a $6^{\circ} \mathrm{F}$ increase in summer temperature-is approximately 10 percent of income. Averaged across all cities, the disamenity value of the B1 scenario is approximately 2.7 percent of income. The disamenity value of the A2 scenario, which projects larger summer and smaller winter temperature increases, is about 5.0 percent of income.

The paper is organized as follows. Section 2 presents the household's location decision and the econometric models we estimate. Section 3 describes the data used in our analysis. Estimation results are presented in Section 4. Section 5 uses these results to evaluate the value of temperature changes projected by the B1 and A2 SRES scenarios. Section 6 concludes the paper.

\section{Household Residential Location Model}

We model households that moved between 1995 and 2000 as selecting their preferred MSA from the set of MSAs in the United States in 2000. Household utility depends on housing, location-specific amenities, moving costs, and expenditures on all other goods (income minus the cost of housing). Utility maximization proceeds in two stages: for each location $\mathrm{j}$ the household optimally allocates its income between housing expenditures and all other goods, yielding an indirect utility function for city $\mathrm{j}$. Then the household chooses the location in which to live that yields the highest indirect utility.

\footnotetext{
8 To represent a range of driving forces for emissions, such as demographic development, socioeconomic development, and technological change, the Intergovernmental Panel on Climate Change (IPCC) developed a set of emissions scenarios. In the SRES, IPCC (2000) describes these scenarios in more detail. We use projections from a climate-friendly scenario (B1) and a more extreme scenario (A2).
} 


\section{Household Location Choice}

In each city, household $i$ chooses the quantity of consumption of a numeraire good and housing to maximize its utility subject to a budget constraint. Assuming a Cobb-Douglas utility function, the utility maximization problem of household $\mathrm{i}$ in location $\mathrm{j}$ is to select consumption $C_{i j}$ and housing $H_{i j}$ to maximize

$$
U_{i j}=C_{i j}^{\alpha_{C}} H_{i j}^{\alpha} H e^{M C_{i j}} e^{g\left(E_{j}\right)}
$$

subject to

$$
C_{i j}+R_{j} H_{i j}=\sum_{m=1}^{N_{i}} w_{m j} \equiv W_{i j}
$$

where $M C_{i j}$ denotes household i's cost of moving to city j, $E_{j}$ is a vector of amenities, $R_{j}$ is the cost of housing, and $w_{m j}$ is the earnings of family member $m$ in city $\mathrm{j}$ ( $W_{i j}$ represents household i's earnings). Substituting optimal values of consumption and housing expenditures into the utility function yields the logarithm of household i's indirect utility from living in city $\mathrm{j},{ }^{9}$

$$
\ln V_{i j}=\beta+\alpha_{W} \ln W_{i j}+M C_{i j}-\alpha_{H} \ln \left(R_{j}\right)+g\left(E_{j}\right)
$$

where the coefficient on the wage, $\alpha_{W} \equiv \alpha_{C}+\alpha_{H}$, and $\alpha_{H} / \alpha_{W}$ is the fraction of income spent on housing. In our empirical model, we allow $\alpha_{W}$ to depend on household characteristics, specifically on the age of the household head and household size, to capture life-cycle effects.

The form of the function $\mathrm{g}($.) depends on what is assumed about preferences for amenities. It might, for example, be reasonable to assume that there is an optimal temperature that households prefer, which would be captured by a quadratic form for $\mathrm{g}($.). Below, we present results using different functional forms for $\mathrm{g}($.). MWTP for an amenity equals the marginal rate of substitution between the amenity and income. For example, if we assume that $g\left(E_{j}\right)=$ $\alpha_{E} \ln E_{j}$, then the MWTP of a household i for climate amenity $E$ is $\left(\alpha_{E} / \alpha_{W}\right)\left(W_{i j} / E_{j}\right)$.

${ }^{9} \beta=\alpha_{C} \ln \left(\frac{\alpha_{C}}{\alpha_{C}+\alpha_{H}}\right)+\alpha_{H} \ln \left(\frac{\alpha_{H}}{\alpha_{C}+\alpha_{H}}\right)$ 


\section{Sinha and Cropper}

Moving costs capture the psychological, search, and out-of-pocket costs of leaving a household's place of origin. We try several specifications of moving costs. Following Bayer et al. (2009), we represent moving costs as a series of dummy variables that reflect whether city $\mathrm{j}$ is outside of the state, Census division, and/or Census region in which household i lived in 1995. Formally,

$$
M C_{i j}=\alpha_{M 0} d_{i j}^{\text {State }}+\alpha_{M 1} d_{i j}^{\text {Division }}+\alpha_{M 2} d_{i j}{ }^{\text {Region }}
$$

where $d_{i j}{ }^{\text {State }}$ denotes a dummy variable that equals one if $\mathrm{j}$ is in a state that is different from the one in which household i lived in $1995, d_{i j}{ }^{\text {Division }}=1$ if location $\mathrm{j}$ is outside of the Census division in which household $\mathrm{j}$ lived in 1995, and $d_{i j}{ }^{\text {Region }}=1$ if location $\mathrm{j}$ lies outside of the Census region in which household i lived in 1995. We also estimate a variant of equation (4) in which $d_{i j}$ State is multiplied by the logarithm of distance between the population-weighted centroid of the state in which household i lived in 1995 and the population-weighted centroid of the state in which city $\mathrm{j}$ is located; $d_{i j}{ }^{\text {Division }}$ and $d_{i j}{ }^{\text {Region }}$ are similarly weighted by the logarithm of distance. 10

\section{Estimation of the Model}

To estimate the household's indirect utility function, we rewrite equation (3) as

$$
\ln V_{i j}+\varepsilon_{i j}=\alpha_{W} \ln \hat{W}_{i j}+M C_{i j}+A_{j}+\varepsilon_{i j}
$$

defining $A_{j}=-\alpha_{H} \ln \left(R_{j}\right)+g\left(E_{j}\right)$. $A_{j}$ combines the unit cost of housing and the average utility of amenities in city j into a city-specific fixed effect. Because we do not observe a household's earnings in all cities, $W_{i j}$ is replaced by its predicted value, described in more detail below. The error term $\varepsilon_{i j}$ combines the error in predicting household i's wages in city $\mathrm{j}$ with household i's unmeasured preferences for city $\mathrm{j}$. Assuming that the idiosyncratic errors are independently and

\footnotetext{
10 Sinha and Cropper (2011) examine additional specifications of moving costs, including costs that depend on the distance between the MSA in which the household lived in 1995 and MSA j (Bishop 2007).
} 
identically distributed Type I extreme value, the probability of household i selecting city $\mathrm{j}$ is given by the conditional logit model,

$$
\operatorname{Pr}\left(\ln V_{i j} \geq \ln V_{i k}, \forall k \neq j\right)=\frac{e^{\alpha_{W} \ln W_{i j}+M C_{i j}+A_{j}}}{\sum_{k=1}^{K} e^{\alpha_{W} \ln W_{i k}+M C_{i k}+A_{k}}} .
$$

Equation (6) is estimated via maximum likelihood techniques, using the McFadden sampling procedure to reduce the size of each household's choice set (McFadden 1978).

In the second stage of the estimation, the MSA-specific fixed effect $A_{j}$ is regressed on $\ln$ $R_{j}$ and location-specific amenities to estimate the parameters of $g\left(E_{j}\right)$. If we were to estimate $A_{j}=-\alpha_{H} \ln \left(R_{j}\right)+g\left(E_{j}\right)+\eta_{j}$, where the error term represents the average utility of unmeasured amenities, it is likely that living costs would be correlated with the error term. We therefore estimate equation (7), 11

$$
\left(A_{j}+\alpha_{H} \ln R_{j}\right)=g\left(E_{j}\right)+\eta_{j}
$$

Our estimate of $\alpha_{\mathrm{H}}$ is based on the median share of income spent on housing in our sample (0.25). Specifically, we set $\alpha_{\mathrm{H}} / \alpha_{\mathrm{W}}=0.25$, where $\alpha_{\mathrm{W}}$ is the estimated coefficient of the log wage from the discrete choice model.

\section{Predicting Wages and Housing Costs}

Estimating equations (6) and (7) requires information on the wages that a household would earn and the cost of housing in all MSAs. Because wages are observed only in the household's chosen location, we estimate a hedonic wage equation for each MSA and use it to predict $W_{i j}$. The hedonic wage equation for MSA $\mathrm{j}$ regresses the logarithm of the hourly wage rate for worker $\mathrm{m}$ in MSA $\mathrm{j}$ on variables $\left(X_{m j}\right)$ measuring the demographic characteristicseducation, experience, and industry and occupation—of worker m. 12

\footnotetext{
11 The second-stage regression yields consistent estimates because the sample size used in the first-stage regression is greater than the square of the number of alternatives (Berry et al. 2004).

12 Equation (8) is estimated using data on full-time workers who are not self-employed. See Sinha (2008) for estimation details.
} 


\section{Sinha and Cropper}

$$
\ln \left(h w_{m j}\right)=\beta_{j}+\Gamma_{j} X_{m j}+v_{m j}
$$

Equation (8) is estimated using data on all workers in the Public Use Microdata sample (PUMS). The coefficients of (8) are used to calculate the earnings of each worker in the sample. ${ }^{13}$ Summing these over all individuals in each household, we obtain predicted household wages for household i in location $\mathrm{j}\left(\hat{W}_{i j}\right)$.

The cost of housing in each location (i.e., $\left.\left\{R_{j}\right\}\right)$ is estimated by including city-specific intercepts in a national hedonic housing market equation, 14

$$
\ln \left(P_{k j}\right)=R_{O W N} O D_{k j}+R_{D C} D C_{k j}+\ln R_{j}+\varphi_{k j}
$$

$P_{k j}$ is the annual cost of owning house $\mathrm{k}$ in city $\mathrm{j}$. It is computed as the sum of the monthly mortgage payment or rent and the cost of utilities, property taxes, and property insurance. $O D_{k j}$ is a dummy variable indicating whether the house was owned or rented, and $D C_{k j}$ is a vector of dwelling characteristics. Utility costs are added to both the costs of owning a home and to rents because heating and cooling requirements vary with climate. We wish to separate these costs from climate amenities. Equation (9) is estimated using data on houses in all MSAs in the 2000 PUMS (Sinha 2008).

It should be emphasized that amenities do not enter either the wage or the housing hedonic equations. The purpose of these equations is to predict earnings opportunities and housing costs facing the household in each city.

\section{Focus on Prime-Aged Migrants}

The equilibrium location model in equations (6) and (7) could be estimated using data on all households. We focus on households that have recently moved (movers) on the grounds that

\footnotetext{
13 We bypass the need to model the labor-leisure choice by making the simplifying assumption that individuals work the same number of hours and weeks in all locations.

14 If we were to estimate a separate housing equation for each metropolitan area, we would have to make an assumption about the housing bundle consumed by each household in each area to predict housing expenditures for a household in each city. The housing price index approach is much cleaner.
} 


\section{Sinha and Cropper}

they are more likely to be in equilibrium than households that have not moved (stayers). 15 Although it is impossible to formally test this proposition, we have estimated the discrete location choice model using movers and stayers (Sinha 2008), with two alternative definitions of moving costs: costs defined relative to the household's location in 1995 and costs defined relative to the head of household's birthplace, as in Bayer et al. (2009). We find that stayers place much less weight on wages than movers do, suggesting that they may not be considering all relevant variables in determining their current location. $16 \mathrm{We}$ therefore measure the preferences of households that have recently moved, acknowledging that their preferences may differ from those of stayers.

We also focus on households whose heads are prime aged (between 26 and 55 years old). In our equilibrium location choice model, the marginal value of an amenity is the rate of substitution between the wage and the amenity in question. To estimate the coefficient on the wage, households must compare differences in wages across locations. This implies that our model is not suitable for estimating the preferences of retirees or households with no wage income. Households with the greatest labor force attachment are those with prime-aged heads. Table 1 describes the employment characteristics of migrant households, by age of household head. The youngest (head aged 25 or younger) and oldest (head over 56 years) age groups are the ones with the lowest labor force attachment. Migrant households whose heads are between 26 and 55 are more likely to have heads who work full time. These households are also more similar in terms of household size and composition. For this reason, our analysis below focuses on households with prime-aged heads.

\section{Data}

The data used to estimate our location model, hedonic wage equations, and hedonic housing equation come from the 5 percent PUMS of the 2000 Census as well as other publicly available data sources.

\footnotetext{
${ }^{15}$ Cragg and Khan (1997) also focus on movers, on the grounds that wages and housing prices in a given location are exogenous to movers, but not to all households.

16 When moving costs are measured from the head of household's birthplace, we find that stayers place only onefifth of the weight on wages that movers do.
} 


\section{Migrant Households and Migration Patterns}

The PUMS contains information on more than 5.6 million households. Table 2 describes households that changed MSAs between 1995 and 2000, for whom both the origin and destination MSA can be identified. 17 Of these 441,393 households, 60.8 percent moved to a different state, 46.9 percent moved to a different Census division, and 36 percent moved to a different Census region. Table 2 shows the origin and destination of households by Census region. Of the households that moved between 1995 and 2000, 32 percent were living in the South in 1995; 28 percent were living in the West. Over 70 percent of these households moved within the region in which they lived in 1995. In contrast, only about half of the movers who lived in the Northeast or Midwest in 1995 remained in their region of origin. On net, households left the Northeast and Midwest for the South and West, a pattern that began after the Second World War and is predicted to continue at least through 2030.

Table 3 compares the characteristics of movers and stayers. Households that moved are, on average, smaller and have fewer children than households that did not move. A higher proportion of households that moved are male-headed, and the heads of households that moved are better educated than the heads of households that did not move.

In addition, heterogeneity among migrant households may affect the value they place on amenities. In equation (5), the marginal rate of substitution between an amenity and wages decreases with $\alpha_{\mathrm{W}}$, the coefficient of the log of household wages. The weight placed on wages and housing costs in a household's utility function is likely to vary with labor force attachment and, possibly, household size. 18 We therefore interact the log of household wages with dummy variables for the age of the household head and household size.

\footnotetext{
${ }^{17}$ Of the 5.66 million households in the PUMS, 1.53 million lived in named MSAs in both 1995 and 2000. Between 1995 and 2000, 28 percent of these households changed location. A household was considered to have moved if the head of household moved.

${ }^{18}$ Note also that, holding the percentage of income spent on housing constant, a larger value of $\alpha_{W}$ implies a larger estimated value of $\alpha_{H}$.
} 


\section{Sinha and Cropper}

\section{Climate Variables}

The climate variables considered in the second stage of the model are summarized in Table 4. All variables are climate normals: the arithmetic mean of a climate variable computed for a 30 -year period. ${ }^{19}$

We focus on mean temperature, measured for the winter (December-February) and summer (June-August) seasons. Previous studies of climate amenities have primarily used mean winter and summer temperature or annual heating and cooling degree days. ${ }^{20,21}$ In studying the impact of climate on agriculture, health, and electricity usage, temperature has been measured by the number of days in various temperature bins (Schlenker and Roberts 2009; Deschenes and Greenstone 2011). The advantage of mean winter and summer temperature is that they capture seasonality, which annual heating and cooling degree days and temperature bins do not. At the same time, correlation between winter and summer temperature and temperature during other seasons of the year means that winter and summer temperature will pick up other temperature impacts: the correlation between mean winter temperature and mean March temperature is 0.97, as is the correlation between mean winter temperature and mean November temperature. Collinearity among mean winter, summer, fall, and spring temperatures, however, makes it impossible to include all four measures in our models.

The precision with which the impact of temperature on location decisions can be estimated depends on temperature variation. Mean winter temperature across the 284 MSAs in our data averages $37^{\circ} \mathrm{F}$, with a standard deviation (s.d.) of $12^{\circ}$; summer temperature averages $73^{\circ}$, with an s.d. of only $6^{\circ}$. Winter and summer temperature are highly correlated $(r=0.76)$.

The models presented in the next section include annual snowfall, mean summer precipitation, and July relative humidity. Mean winter precipitation, which averages 9.4 inches (s.d. $=5$ inches), is highest in the Pacific Northwest and the Southeast, where winter

\footnotetext{
19 The temperature and summer precipitation data are for the period 1970 to 2000 . July relative humidity, annual snowfall, and percentage possible sunshine are measured for the period 1960 to 1990.

${ }^{20}$ Heating and cooling degree days are computed by the National Climatic Data Center using the average of the high and low temperatures for a day. If this is greater than $65^{\circ} \mathrm{F}$, it results in (average temperature-65) cooling degree days. If the average temperature is less than $65^{\circ}$, it results in (65-average temperature) heating degree days.

${ }^{21}$ Graves and Mueser (1993) and Kahn (2009) use mean January and mean July temperatures; Cragg and Kahn (1997, 1999) use mean February and mean July temperatures. Roback (1982), Blomquist et al. (1988), and Gyourko and Tracy (1991) use annual heating and cooling degree days, as do Albouy et al. (2011).
} 


\section{Sinha and Cropper}

precipitation comes in the form of rain. In preliminary analyses, winter precipitation appeared to be a disamenity, but this effect was statistically significant only at low levels of precipitation. This suggested that snowfall should replace winter precipitation: cities with significant snowfall have lower levels of winter precipitation (the correlation between annual snowfall and winter precipitation is -0.36 ), and snow is likely to be more of a disamenity than rain.

Summer precipitation, which averages 11 inches (s.d. $=5$ inches), is heaviest in the southeastern United States. Surprisingly, the correlation between summer precipitation and winter precipitation is very low $(\mathrm{r}=0.03)$, as is the correlation between summer precipitation and annual snow $(\mathrm{r}=-0.02)$. Mean July relative humidity is 69 percent (s.d. $=7$ percent) and is not highly correlated with either winter temperature $(\mathrm{r}=0.06)$ or summer temperature $(\mathrm{r}=0.14)$.

Following the literature, we also include the percentage of possible sunshine, defined as the total time that sunshine reaches the surface of the earth, expressed as a percentage of the maximum amount possible from sunrise to sunset.

\section{Nonclimate Amenities}

The nonclimate amenity variables used in the second stage of the model are also summarized in Table 4. These include amenity measures typically used in quality-of-life studies as well as variables that are likely to be correlated with climate, such as elevation, visibility, and measures of parks and recreation opportunities. Our desire is to be as inclusive as possible. Because climate changes slowly, we cannot use panel data to value climate amenities. We therefore strive to avoid problems of omitted variable bias by including a variety of locationspecific amenities in our models and by using different functional forms for our temperature variables.

It is especially important that we control for population. If the first stage of the location model were estimated without including wages and moving costs, the location-specific intercepts would reflect the proportion of the sample locating in each city. Because people are more likely to migrate to more populous cities, it is imperative that we control for city population when estimating equation (7).

Other (dis)amenities for which we control include air pollution (fine particulate matter $\left[\mathrm{PM}_{2.5}\right]$ ), an index of violent crime, visibility (percentage of hours with visibility greater than 10 


\section{Sinha and Cropper}

miles), square miles of parks within the MSA, elevation measured at the population-weighted centroid of the MSA, and distance from the population-weighted centroid of each MSA to the nearest coast. We also include indices from the Places Rated Almanac (Savageau and D'Agostino 2000) that measure how well each city functions in terms of transportation, education, health, and recreation opportunities. We include dummy variables for the nine Census divisions to capture regional variation in amenities not otherwise controlled for as well as differences in the cost of nonhousing goods. In our preferred specifications, amenities other than winter and summer temperature explain at least 85 percent of the variation in the second-stage dependent variables.

\section{Estimation Results}

\section{Hedonic Wage Equations}

The results of the hedonic wage equations are summarized in Appendix Table A-1. Most variables are significant at the 5 percent level for all MSAs. Older workers earn more, but the age premium declines with age, as expected. Married individuals and males earn more than single workers and females. People who speak English well earn more than those who have difficulty with the language, and Hispanics earn less than non-Hispanics. The returns to education are positive. Occupation dummies also have the expected signs (i.e., occupations requiring more education and/or white collar occupations are associated with higher wages). We find, as do Cragg and Kahn (1997), that the returns to different occupations and industries vary significantly across MSAs, suggesting that the assumption of a national labor market, made in earlier hedonic studies, is inappropriate.

\section{Hedonic Housing Market Equation}

The results of the hedonic housing equation are presented in Appendix Table A-2. An owner-occupied house carries a premium. Houses with greater numbers of rooms and bedrooms are worth more than houses with fewer rooms. Houses on smaller acreage are worth less than houses on larger lots. Older houses have lower values than newer houses. All housing characteristics are statistically significant at the 5 percent level, as are 93 percent of the MSAspecific dummy variables (the $\left\{\operatorname{lnR}_{j}\right\}$ ). The MSA-specific dummies, which represent housing 
cost indices, seem reasonable. For example, Boston has a higher index than Seattle, which is in turn more expensive than Washington, DC. The MSAs in California, New York, and New Jersey have very high costs of living.

\section{Results from the First Stage of the Migration Model}

We estimated equation (6) using households that moved between 1995 and 2000 whose household head was between 26 and 55 years of age. To make the analysis computationally tractable, we used a sample of migrant households from the PUMS and the McFadden sampling procedure to construct the choice set facing each household. The sample of households with prime-aged heads numbers 115,623. 22 Following McFadden (1978) the choice set for each household includes the chosen MSA and 19 other randomly selected MSAs.

We experimented with various specifications of moving costs (Sinha and Cropper 2011): using dummy variables to indicate that an MSA is outside of the state, Census region, and Census division in which the household lived in 1995 (equation [4]); weighting each dummy variable by distance; and weighting each dummy variable by the log of distance. 23 Weighting state, division, and region dummies by distance captures the fact that households in the Northeast are more likely to move to the South than to the West (see Table 2). The best-fitting of the three models is the one that weights each dummy variable by the log of distance.

Table 5 presents estimates of the migration equation. Model 1 includes all households with heads between 26 and 55 years old. Model 2 allows the coefficient on the wage among prime-aged movers to vary by household size. In Model 3, the coefficient on the wage for primeaged movers is allowed to vary by age group. The weight attached to wages in the migration decision depends on the age of the household head and household size. The coefficient on the wage for one- and two-person prime-aged households (Model 2) is about 47 percent higher than the coefficient for households with more than two people. The weight placed on wages by prime-

\footnotetext{
22 Three categories were created for household heads aged 26 to 35,36 to 45 , and 46 to 55 years. A 50 percent random sample was chosen in each category to ensure a sufficient number of observations in each age group in every MSA.

$23 d_{i j}^{\text {State }}$ is multiplied by the distance between the population-weighted centroid of the state in which household $\mathrm{i}$ lived in 1995 and the population-weighted centroid of the state in which city j is located; $d_{i j}{ }^{\text {Division }}$ and $d_{i j}{ }^{\text {Region }}$ are similarly weighted by distance.
} 


\section{Sinha and Cropper}

aged households (Model 3) declines with age: it is approximately twice as high for households headed by a 26- to 35 -year-old as for households headed by a 46- to 55-year-old. Other things equal, the higher the weight placed on wages, the lower the MWTP for amenities, holding income constant. This implies that younger households and households without children will have a lower MWTP than older households and households with children, holding income constant.

The MSA fixed effects estimated in stage one (the $\left.\left\{A_{j}\right\}\right)$ represent the average utility obtained from location-specific amenities net of housing costs. Interestingly, the correlation between the $\left\{A_{j}\right\}$ for any pair of models in Table 5 is never lower than 0.99. As discussed above, more populous cities have higher $\mathrm{A}_{\mathrm{j}} \mathrm{s}$. (The correlation between the $\left\{\mathrm{A}_{\mathrm{j}}\right\}$ and the log of MSA population is 0.89 .) This makes it imperative to control for population in the second stage.

\section{Results from the Second Stage of the Migration Model}

In the second stage of the estimation, MSA fixed effects are regressed on the log of the housing cost index $\left(\ln R_{j}\right.$ ) and amenities. Because living costs are likely to be correlated with the error term $\eta_{\mathrm{j}}$, the fraction of income spent on housing is set equal to 0.25 , which is the median share of income spent on housing in the movers sample, and $\alpha_{\mathrm{H}} \ln R_{j}$ is added to the dependent variable (equation [7]).

The estimate of $\alpha_{H}$ varies with the coefficient on the wage in the first stage of the model. Holding constant the fraction of income spent on housing, a higher value of the wage coefficient implies a higher value of $\alpha_{\mathrm{H}}{ }^{24}$ If the fraction of income spent on housing is 0.25 , a wage coefficient of 1.62 implies a value of $\alpha_{H}$ of 0.41 . A wage coefficient of 2.03 implies a value of $\alpha_{H}$ $=0.51$ in equation (7). This means that a second-stage equation should be estimated for each value of the wage coefficient in the first stage. Below, we focus on results from the sample of all prime-aged movers (Model 1).

In Section 5, we use the value of changes in mean winter and summer temperature to value SRES climate scenarios. Two important considerations are what form these variables should take in the second-stage models and what other variables should be held constant. We

\footnotetext{
24 The fraction of income spent on housing is $\alpha_{H} / \alpha_{W}$, where $\alpha_{W}$ is the coefficient on the wage. Therefore $\alpha_{H}=$ $0.25 \alpha_{\mathrm{W}}$.
} 


\section{Sinha and Cropper}

have tried cubic, quadratic, and logarithmic specifications of the temperature variables. In evaluating the impact of the temperature and precipitation variables, we controlled for mean July relative humidity, annual snowfall, the logarithm of summer precipitation, and percentage sunshine as well as the nonclimate variables listed above. Results from our preferred specifications are reported in Table 6. Models 4 and 5 include Census division fixed effects; Models 6 and 7 exclude Census division fixed effects but cluster standard errors at the Census division level.

All specifications indicate that increasing winter temperature increases mean utility, at a decreasing rate. In quadratic specifications, mean utility peaks at $49^{\circ} \mathrm{F}$ when Census division dummies are included in the model and at $60^{\circ}$ when they are excluded. Marginal effects from the quadratic specifications are statistically significant up to $49^{\circ}$ and insignificant at higher temperatures. 25 When the log of winter temperature replaces the quadratic function, its coefficient is negative and significant at the 0.01 level and unaffected by division fixed effects. The marginal effect of winter temperature on utility is presented in Table 7 and plotted in Figure 1 for the models without division fixed effects. The marginal utility of winter temperature is very similar for the models without division fixed effects for temperatures between $27^{\circ}$ and $47^{\circ}$, the sample interquartile range.

All models indicate that increasing summer temperature reduces utility, but whether the marginal disutility of $\mathrm{s}$ ummer temperature increases or decreases with temperature varies with equation specification. Results are statistically significant and robust to the inclusion of division fixed effects when we use the log of summer temperature (Models 5 and 7). These models impose the restriction that marginal disutility declines as temperature increases. Entering summer temperature in quadratic form implies that the marginal disutility of summer temperature increases as temperature rises when division fixed effects are included in the model but decreases with temperature when division dummies are excluded. Marginal disutility is, however, significant only when division dummies are excluded from the equation (Model 6) and only for temperatures in the range of $60^{\circ}$ to $80^{\circ} \mathrm{F}$. This is not surprising: there is little withindivision variation in summer temperature, and few mean summer temperatures lie outside of the

\footnotetext{
${ }^{25}$ As shown in Table 7, winter temperature becomes a disamenity at very high temperatures; however, the marginal effects are not statistically significant.
} 


\section{Sinha and Cropper}

$60^{\circ}$ to $80^{\circ}$ range using climate averages for the 1970 to 2000 period. Because of the small within-division variation in summer temperature, we focus on the results from models without division dummies (Models 6 and 7) for the remainder of the paper. 26

As Table 7 and Figure 2 suggest, the marginal disutility of summer temperature is quite similar in the logarithmic and quadratic models between $65^{\circ}$ and $80^{\circ} \mathrm{F}$ (the sample interquartile range). The marginal disutility of higher temperatures actually decreases slightly with temperature, which may reflect the fact that once people have adapted to higher temperatures (e.g., by spending less time outdoors), additional increases in temperature yield (slightly) less disutility.

The marginal effects in Table 7 imply that, in most MSAs, the utility of a $1^{\circ} \mathrm{F}$ increase in mean winter temperature is less than the utility of a $1^{\circ}$ decrease in mean summer temperature. The median average winter temperature in our sample is $35^{\circ}$, and the median average summer temperature is $73^{\circ}$. Whether using the quadratic or logarithmic models, the utility of a decrease in summer temperature from $73^{\circ}$ to $72^{\circ}$ exceeds the utility of increasing temperature from $35^{\circ}$ to $36^{\circ}$. Only at a mean winter temperature of $25^{\circ}$ or lower in the case of quadratic utility $\left(20^{\circ}\right.$ or below in the case of logarithmic utility) does the utility of an increase in winter temperature exceed the utility of reducing summer temperature at $73^{\circ}$.

\section{MWTP for Climate Amenities}

The coefficients in Tables 5 and 7 may be combined to estimate what households would pay for marginal changes in winter and summer temperature (Table 8). In interpreting estimates of MWTP for mean winter and summer temperature, it should be emphasized that a $1^{\circ} \mathrm{F}$ change in temperature over the months of December through February is highly correlated with a $1^{\circ}$ change in November and March temperatures; a similar relationship holds for summer and September temperatures. ${ }^{27}$ We also note that mean daily temperature is highly correlated with daily temperature extremes; hence, a $1^{\circ}$ decrease in mean winter temperature will reduce

\footnotetext{
${ }^{26} \mathrm{We}$ also note that there is little within-division variation in snowfall and humidity: these variables become statistically significant when division dummies are removed.

${ }^{27}$ We have tried expanding the definition of winter to include November and March and summer to include September. The models presented in Table 6 produce better fits than the models estimated with expanded definitions of winter and summer temperature.
} 


\section{Sinha and Cropper}

minimum daily temperature, and a reduction in mean summer temperature will reduce maximum daily temperature.

Table 8 indicates that, on average, a prime-aged household is willing to pay between 1.3 and 1.4 percent of its income for a $1^{\circ} \mathrm{F}$ increase in winter temperature at $35^{\circ}$ (the sample median) and must be compensated 2 percent of its income for a $1^{\circ}$ increase in temperature from $75^{\circ}$ to $76^{\circ}$ in the summer. This amount varies with temperature and with household characteristics. MWTP for a $1^{\circ}$ increase in winter temperature is only about 1 percent of income for households with heads between 26 and 35 years old, whereas it is about 2 percent of income for households headed by 46- to 55-year-olds. The greater value placed on climate by households with older heads agrees with the findings of Cragg and Kahn (1997). Table 8 indicates that larger households have higher MWTP (in absolute terms) than smaller households, although the difference is less dramatic.

\section{WTP for Temperature Changes}

We use the results of the equilibrium location model to estimate what households would pay for temperature changes that are projected to occur over the period 2020 to 2050 under two SRES climate scenarios. Specifically, we use the results of the Hadley III model to project mean winter and summer temperature over the 2020 to 2050 period in 26 US cities (shown in Figure 3) under the B1 and A2 SRES scenarios. 28 We estimate WTP for these temperature changes, compared with climate averages over the period 1970 to 2000 . In computing WTP, we ask what a household in each city would pay for the projected changes in winter and summer temperature, assuming that the household must remain in the city. 29

The B1 SRES scenario, a more climate-friendly scenario than the A2, leads to an atmospheric carbon dioxide $\left(\mathrm{CO}_{2}\right)$ concentration of 550 parts per million (ppm) in the year 2100 , whereas the $\mathrm{A} 2$ scenario results in an atmospheric $\mathrm{CO}_{2}$ concentration of 850 ppm by 2100 (Karl et al. 2009). Over the period 2020 to 2050, however, the temperature projections for the United States do not differ dramatically between the two scenarios. Both scenarios project warmer

\footnotetext{
28 Data from the Hadley III model were generously provided by Wolfram Schlenker.

${ }^{29}$ Formally, we used the deterministic component of the household's utility function to compute compensating variation for the predicted change in winter and summer temperature, holding the household's location fixed.
} 


\section{Sinha and Cropper}

winters and warmer summers; however, the B1 scenario projects, on average, warmer winters than the A2 scenario for the cities we consider - an average increase in winter temperature of $3.3^{\circ} \mathrm{F}$ under $\mathrm{B} 1$ and $2.0^{\circ} \mathrm{F}$ under A2. Projections of increases in summer temperature for the two scenarios are slightly higher under the A2 scenario (on average, $3.7^{\circ} \mathrm{F}$ ) than under the B2 scenario $\left(3.3^{\circ} \mathrm{F}\right)$.

The variation in temperature changes across the 26 cities in Table 9 is, however, considerable. Under the B1 scenario, cities in the Northeast Census region experience increases in winter temperature between $4.5^{\circ}$ and $5.4^{\circ} \mathrm{F}$, whereas cities in the West experience increases between $1.0^{\circ}$ and $2.9^{\circ}$. In general, cities at lower latitudes experience larger increases in mean summer temperature than cities at higher latitudes under both scenarios.

Table 9 displays household WTP for each simulated temperature change using the deterministic portion of the household's utility function (Herriges and Kling 1999). ${ }^{30}$ We assume that a household located in a given city experiences the temperature change for that city shown in Table 9, holding all other prices and amenities constant, and must remain in the city. This overstates (in absolute value) compensating variation for the temperature changes, because the household is not allowed to adjust by moving. 31

Under each scenario, the welfare impacts of temperature changes, averaged across all cities, are robust to the form of the utility function. The average welfare loss under the B1 scenario (population weighted) is the same for both utility functions - about 2.7 percent of income. Under the A2 scenario it is about 5.0 percent of income (population weighted) using either utility function. Estimates of net welfare impacts in individual cities do vary somewhat with the form of the utility function. As indicated in Figure 1, cities with winter temperatures between $20^{\circ}$ and $35^{\circ} \mathrm{F}$ benefit more from warmer winters using a quadratic utility function; hence the benefits of increases in winter temperatures in the Northeast are higher using the quadratic specification of temperature. Cities with milder winters (such as West Palm Beach, Orlando, Dallas, and Houston) benefit more from increases in winter temperature using the logarithmic utility function.

\footnotetext{
30 Computations in Table 9 are based on Model 1 of Table 5.

${ }^{31}$ We could compute expected consumer surplus, allowing temperatures to change simultaneously and allowing households to move. This would, however, need to be accompanied by an analysis of how wages and housing prices would change across cities, which is beyond the scope of this paper.
} 


\section{Sinha and Cropper}

Welfare impacts vary considerably across cities. Under the B1 scenario, several cities experience welfare gains. These include cities in the northeastern region and midwestern cities such as Minneapolis, Minnesota, and Fargo, North Dakota, whose projected increases in winter temperature exceed increases in summer temperature. Under the A2 scenario, increases in summer temperatures are greater than increases in winter temperatures in almost all cities; hence, a typical household experiences a net welfare loss under the A2 scenario in all cities except Fargo, North Dakota. Cities experiencing high welfare losses under both scenarios include Fresno, California, and Dallas-Fort Worth, Texas, because projected temperature changes for summer are much larger than those for winter.

Table 9 suggests that average temperature changes of about $2^{\circ} \mathrm{C}$ would impose significant welfare losses — on average, about 2.7 percent of income — based on the cities examined in Table 9. These losses are larger than those reported by Albouy et al. (2011) using a hedonic approach. Albouy et al. (2011) regressed a weighted average of wages (net of taxes) and housing prices on local amenities using data from the 2000 PUMS. They found that households are willing to pay more to reduce cooling degree days than heating degree days and that the marginal disutility to reduce severe heat is not statistically different from the marginal disutility to reduce moderate heat. When these results are used to value temperature changes associated with the A2 SRES scenario in 2090 to 2100, welfare losses are between 1.5 and 2.0 percent of household income. There are many reasons for differences in the magnitude of our results, but the higher values that we obtained using a discrete location choice model are consistent with the differences between the discrete choice and hedonic approaches found by Bayer et al. (2009).

\section{Conclusions}

Our analysis indicates that US households that moved between 1995 and 2000 considered climate amenities, as well as housing prices, earnings opportunities, and moving costs, in their location decisions. They were willing to pay for increases in winter temperature and decreases in summer temperature as well as for less humid summers and less snowfall. Moreover, MWTP for higher winter temperature decreases as temperature increases. The disamenity of hotter summers appears to decrease slightly with mean summer temperature, but, because mean summer temperature varies less than mean winter temperature, this effect is estimated less precisely than for winter temperature. 


\section{Sinha and Cropper}

Holding income constant, the models indicate that households with heads between 46 and 55 years of age were willing to pay almost twice what a household headed by a 26- to 35-yearold would pay for an improvement in a climate amenity. Households with more than two members were willing to pay about 50 percent more than households with one or two members for a climate amenity.

Based on these results, summer temperature is more of a disamenity than winter temperature. Using results for all prime-aged households, the average rate of substitution between wages and temperature - evaluated at sample medians $\left(35^{\circ} \mathrm{F}\right.$ winter temperature and $73^{\circ} \mathrm{F}$ summer temperature) - implies that a $1^{\circ}$ increase in winter temperature combined with a $1^{\circ}$ increase in summer temperature would reduce welfare by about 0.25 percent of income. The marginal disutility of winter temperature, however, increases as temperature falls. Thus, MWTP for a $1^{\circ}$ increase in winter temperature from a baseline of $25^{\circ} \mathrm{F}$ (or lower) would be greater than MWTP for a $1^{\circ}$ decrease in summer temperature.

When these results are combined with projections of temperature changes associated with the B1 SRES scenario over the period 2020 to 2050, they imply that, averaged across 26 cities, WTP to avoid the projected changes in climate is about 2.7 percent of income. For the A2 scenario, the loss is, on average, about 5 percent of income. These figures correspond to population-weighted average temperature changes of $3.3^{\circ} \mathrm{F}\left(2.0^{\circ} \mathrm{F}\right)$ in the winter under the $\mathrm{B} 1$ (A2) scenario and $3.3^{\circ} \mathrm{F}\left(3.7^{\circ} \mathrm{F}\right)$ in the summer. Under the B1 scenario, some cities in the Northeast and Midwest benefit on net from larger increases in winter temperatures than in summer temperatures. Under the A2 scenario, however, the larger projected increases in summer temperatures than in winter temperatures result in a net welfare loss in 25 of the 26 cities examined. We emphasize that these losses do not account for adaptation to climate change: the losses do not allow households to move in response to temperature changes. So they should be regarded as upper bounds to climate damages.

Estimates for the United States of market-based damages associated with climate change have typically been in the range of 1 percent of gross domestic product for an increase in mean temperature of $2^{\circ} \mathrm{C}$ (National Research Council 2010). Our results suggest that the amenity value of climate could significantly increase estimates of climate damages, even for moderate temperature increases. 


\section{References}

Albouy, D., W. Graf, R. Kellogg, and H. Wolff. 2011. Climate Amenities, Climate Change and American Quality of Life. Unpublished paper.

Bayer, P., N. Keohane, and C. Timmins. 2009. Migration and Hedonic Valuation: The Case of Air Quality. Journal of Environmental Economics and Management 58: 1-14.

Bayer, P., R. McMillan, and K. Reuben. 2004. An Equilibrium Model of Sorting in an Urban Housing Market. NBER working paper no. 10865. Cambridge, MA: National Bureau of Economic Research.

Bayer, P., and C. Timmins. 2007. Estimating Equilibrium Models of Sorting across Locations. The Economic Journal 117(518): 353-374.

Berry, S., J. Levinsohn, and A. Pakes. 1995. Automobile Prices in Market Equilibrium. Econometrica 63(4): 841-890.

Berry, S., O.B. Linton, and A. Pakes. 2004. Limit Theorems for Estimating the Parameters of Differentiated Product Demand Systems. Review of Economic Studies 71(3): 613-654.

Bishop, K.C. 2007. A Dynamic Model of Location Choice and Hedonic Valuation. Unpublished paper. Durham, NC: Duke University.

Blomquist, G.C., M.C. Berger, and J.P. Hoehn. 1988. New Estimates of Quality of Life in Urban Areas. American Economic Review 78(1): 89-107.

Cragg, M., and M. Kahn. 1997. New Estimates of Climate Demand: Evidence from Location Choice. Journal of Urban Economics 42: 261-284.

Cragg, M., and M. Kahn. 1999. Climate Consumption and Climate Pricing from 1940 to 1990. Regional Science and Urban Economics 29: 519-539.

Deschenes, O., and M. Greenstone. 2011. Climate Change, Mortality, and Adaptation: Evidence from Annual Fluctuations in Weather in the US. American Economic Journal: Applied Economics 3(4): 152-185. 


\section{Sinha and Cropper}

Graves, P., and P. Mueser. 1993. The Role of Equilibrium and Disequilibrium in Modeling Regional Growth and Decline: A Critical Reassessment. Journal of Regional Science 33(1): 69-84.

Gyourko, J., and J. Tracy. 1991. The Structure of Local Public Finance and the Quality of Life. Journal of Political Economy 99(4): 774-806.

Herriges, J.A., and C.A. Kling. 1999. Nonlinear Income Effects in Random Utility Models. Review of Economics and Statistics 99(1): 62-72.

Intergovernmental Panel on Climate Change. 2000. Special Report: Emissions Scenarios: Summary for Policymakers. A Special Report of IPCC Working Group III. Cambridge, UK: Cambridge University Press.

Kahn, M. 2009. Urban Growth and Climate Change. Annual Review of Resource Economics 1: $333-350$.

Karl, Thomas R., Jerry M. Melillo, and Thomas C. Peterson (eds.). 2009. Global Climate Change Impacts in the United States. Cambridge, UK: Cambridge University Press.

Klaiber, H.A., and D.J. Phaneuf. 2010. Valuing Open Space in a Residential Sorting Model of the Twin Cities. Journal of Environmental Economics and Management 60(2): 57-77.

McFadden, D. 1978. Modeling the Choice of Residential Location. In Spatial Interaction Theory and Planning Models, edited by A. Karlqvist, L. Lundquist, F. Snickars, and J. Weibull. Amsterdam: North Holland.

National Research Council. 2010. Hidden Costs of Energy: Unpriced Consequences of Energy Production and Use. Washington, DC: National Academies Press.

Roback, J. 1982. Wages, Rents, and the Quality of Life. Journal of Political Economy 90(6): $1257-1278$.

Savageau, D., and R. D’Agostino. 2000. Places Rated Almanac: Millennium Edition. New York: Hungry Minds Inc.

Schlenker, W., and M. Roberts. 2009. Nonlinear Temperature Effects Indicate Severe Damages to US Crop Yields under Climate Change. Proceedings of the National Academy of Sciences 106(37): 15594-15598. 
Sinha, P. 2008. The Value of Climate Amenities: A Disequilibrium Approach. Ph.D. diss., University of Maryland, College Park.

Sinha, P., and M. Cropper. 2011. The Value of Climate Amenities: Evidence from US Migration Decisions. Washington, DC: US Environmental Protection Agency.

Smith, V.K. 1983. The Role of Site and Job Characteristics in Hedonic Wage Models. Journal of Urban Economics 13(3): 296-321.

\section{Figures and Tables}

(See following pages.) 
Table 1. Descriptive Statistics (Percentages) of Migrants by Age of Household Head

\begin{tabular}{|c|c|c|c|c|c|c|}
\hline Variable & $\begin{array}{l}\text { Ages } \\
\text { 16-25 }\end{array}$ & $\begin{array}{l}\text { Ages } \\
\text { 26-35 }\end{array}$ & $\begin{array}{l}\text { Ages } \\
\text { 36-45 }\end{array}$ & $\begin{array}{l}\text { Ages } \\
46-55\end{array}$ & $\begin{array}{c}\text { Ages } \\
56-65\end{array}$ & $\begin{array}{l}\text { Ages } \\
>65\end{array}$ \\
\hline Married & 22.4 & 50.5 & 58.6 & 56.3 & 58.5 & 46.5 \\
\hline \multicolumn{7}{|l|}{ Household size } \\
\hline 1-person hh & 63.3 & 29.6 & 25.9 & 31.3 & 34 & 58.3 \\
\hline 2-person hh & 20.3 & 29.5 & 19.5 & 32.4 & 49.2 & 36 \\
\hline 3-person hh & 9.26 & 17.1 & 16.4 & 15.6 & 9.51 & 3.6 \\
\hline$>3$-person hh & 7.16 & 23.9 & 38.3 & 20.8 & 7.28 & 2.14 \\
\hline \multicolumn{6}{|l|}{ Usual hours worked per } & week \\
\hline Hours worked $=0$ & 12.1 & 6.4 & 8.5 & 13 & 35.7 & 84.9 \\
\hline Hours worked $>0$ and $<30$ & 33.2 & 7.3 & 5.9 & 6.5 & 11 & 7.6 \\
\hline $\begin{array}{l}\text { Hours worked }>30 \text { and }< \\
60\end{array}$ & 51.8 & 81.2 & 80.3 & 76.2 & 50.9 & 7.3 \\
\hline Hours worked $>60$ & 2.9 & 5.1 & 5.2 & 4.3 & 2.3 & 0.3 \\
\hline \multicolumn{7}{|l|}{ Weeks worked in a year } \\
\hline Weeks worked $=0$ & 12.1 & 6.4 & 8.5 & 13 & 35.7 & 84.9 \\
\hline Weeks worked $>0$ and $<30$ & 35.3 & 8.9 & 7.8 & 8.6 & 12.7 & 6.2 \\
\hline Weeks worked $>0$ and $<30$ & 52.6 & 84.6 & 83.7 & 78.4 & 51.6 & 8.9 \\
\hline
\end{tabular}

Note: Figures in table are percentages.

Table 2. Origin and Destination of Migrants by Census Region

\begin{tabular}{cccccc}
\hline \multirow{2}{*}{ Region } & \multicolumn{5}{c}{ Region (2000) } \\
\cline { 2 - 4 }$(\mathbf{1 9 9 5 )}$ & Midwest & Northeast & South & West & Total \\
\cline { 2 - 5 } & & 5,130 & 20,900 & 13,200 & $\mathbf{7 8 , 1 0 0}$
\end{tabular}


Sinha and Cropper

\begin{tabular}{lccccc} 
& $-8.8 \%$ & $-1.2 \%$ & $-4.7 \%$ & $-3.0 \%$ & $-\mathbf{1 7 . 7 \%}$ \\
\hline Northeast & 5,230 & 55,500 & 29,700 & 10,200 & $\mathbf{1 0 1 , 0 0 0}$ \\
& $-1.2 \%$ & $-12.6 \%$ & $-6.7 \%$ & $-2.3 \%$ & $-\mathbf{2 2 . 8 \%}$ \\
\hline South & 11,700 & 11,900 & 99,800 & 17,300 & $\mathbf{1 4 1 , 0 0 0}$ \\
& $-2.7 \%$ & $-2.7 \%$ & $-22.6 \%$ & $-3.9 \%$ & $\mathbf{- 3 1 . 9 \%}$ \\
\hline West & 7,710 & 5,830 & 18,700 & 89,800 & $\mathbf{1 2 2 , 0 0 0}$ \\
& $-1.8 \%$ & $-1.3 \%$ & $-4.2 \%$ & $-20.3 \%$ & $\mathbf{- 2 7 . 6 \%}$ \\
\hline Total & $\mathbf{6 3 , 5 0 0}$ & $\mathbf{7 8 , 4 0 0}$ & $\mathbf{1 6 9 , 0 0 0}$ & $\mathbf{1 3 0 , 0 0 0}$ & $\mathbf{4 4 1 , 0 0 0}$ \\
& $\mathbf{- 1 4 . 4 \%}$ & $\mathbf{- 1 7 . 8 \%}$ & $-\mathbf{3 8 . 3} \%$ & $\mathbf{- 2 9 . 6 \%}$ & \\
\hline
\end{tabular}


Table 3. Descriptive Statistics of Migrants versus Nonmigrants ${ }^{a}$

\begin{tabular}{|c|c|c|c|}
\hline & Variable & $\begin{array}{c}\text { Movers } \\
(\mathrm{N}=\mathbf{4 4 1 , 3 9 3 )}\end{array}$ & $\begin{array}{c}\text { Stayers } \\
(\mathrm{N}=\mathbf{1 , 0 8 3 , 9 8 6 )}\end{array}$ \\
\hline $\begin{array}{l}\text { Gender of head of household } \\
\text { (proportions) }\end{array}$ & Male & 64.1 & 60.4 \\
\hline \multirow{3}{*}{$\begin{array}{l}\text { Race of head of household } \\
\text { (proportions) }\end{array}$} & White & 75.9 & 73 \\
\hline & Black & 11 & 15 \\
\hline & Other & 13.1 & 12 \\
\hline $\begin{array}{l}\text { Marital status of head of } \\
\text { household (proportions) }\end{array}$ & Married & 46.4 & 47.1 \\
\hline \multirow{5}{*}{$\begin{array}{l}\text { Education of head of household } \\
\text { (proportions) }\end{array}$} & No high school & 10.7 & 19.3 \\
\hline & High school & 17.8 & 25.5 \\
\hline & Some college & 34.2 & 30.4 \\
\hline & College graduate & 23.4 & 16.4 \\
\hline & Postgraduate education & 13.9 & 8.46 \\
\hline $\begin{array}{l}\text { Age of head of household } \\
\text { (Mean) }\end{array}$ & Age & 38.4 & 42.9 \\
\hline $\begin{array}{l}\text { Household wage earnings } \\
\text { (Mean) }\end{array}$ & $\begin{array}{l}\text { Sum of the wage earnings } \\
\text { of all household members }\end{array}$ & 44,900 & 43,900 \\
\hline Total household income (Mean) & $\begin{array}{l}\text { Sum of wage, business } \\
\text { and farm incomes and } \\
\text { income from other } \\
\text { sources }^{b} \text { of all household } \\
\text { members }\end{array}$ & 63,600 & 56,900 \\
\hline \multirow[t]{5}{*}{ Size of household } & 1 member & 39.9 & 30.1 \\
\hline & 2 members & 27.4 & 26.6 \\
\hline & 3 members & 13.2 & 16.9 \\
\hline & 4 members & 11.4 & 14.7 \\
\hline & More than 4 members & 8.15 & 11.8 \\
\hline
\end{tabular}




\begin{tabular}{llcc}
\hline & \multicolumn{1}{c}{ Variable } & $\begin{array}{c}\text { Movers } \\
\mathbf{( N = 4 4 1 , 3 9 3 )}\end{array}$ & $\begin{array}{c}\text { Stayers } \\
(\mathbf{N}=\mathbf{1 , 0 8 3 , 9 8 6})\end{array}$ \\
\hline Number of children in the & 0 children & 68.4 & 54.7 \\
household & 1 child & 13.3 & 19 \\
& 2 children & 11.7 & 16.4 \\
& 3 children & 4.68 & 6.85 \\
& 4 children & 1.39 & 2.14 \\
& $>4$ children & 0.54 & 0.95 \\
\hline
\end{tabular}

${ }^{a}$ There are 5,663,214 households in the PUMS data. We know the MSAs in which households lived in 1995 and 2000 for 26.9 percent of these households (1,525,379 households). For the remaining households, we do not have values for the MSA variable. This may be because these were households that did not live in MSAs in either of the two years, migrated to the United States from abroad, or for which we have missing values for either of the two years.

${ }^{b}$ Income from other sources would include Social Security income; welfare (public assistance) income; Supplementary Security income; interest, dividend, and rental income; retirement income; and other income. 
Table 4. Descriptive Statistics of Amenity Variable

\begin{tabular}{|c|c|c|c|c|c|}
\hline Variable & $\mathbf{N}^{\mathbf{a}}$ & Mean & $\begin{array}{l}\text { Std. } \\
\text { Dev. }\end{array}$ & Minimum & Maximum \\
\hline Mean $\mathrm{PM}_{2.5}$ (micrograms/cubic meter) & 284 & 12.8 & 2.88 & 5.38 & 19.5 \\
\hline $\begin{array}{l}\text { Violent crime rate (number of violent crimes } \\
\text { per } 1,000 \text { persons) }\end{array}$ & 284 & 4.56 & 2,210 & 0.0686 & 12.3 \\
\hline Population $(1,000 \mathrm{~s})$ & 284 & 761 & 1210 & 102 & 9520 \\
\hline Distance to coast (miles) & 284 & 141 & 170 & 0.00924 & 824 \\
\hline Avg. elevation (miles) & 284 & 0.197 & 0.273 & 0.000283 & 1.62 \\
\hline Area of parks (square miles) & 284 & 193 & 584 & 0.00 & 5480 \\
\hline Visibility $>10$ Miles ( $\%$ of hours) & 284 & 46.1 & 19.5 & 5 & 85.5 \\
\hline Annual snowfall (inches) & 284 & 20.4 & 21.4 & 0.00 & 84.1 \\
\hline July relative humidity (\%) & 284 & 66.2 & 10.9 & 22.5 & 78 \\
\hline Avg. winter temperature $\left({ }^{\circ} \mathrm{F}\right)$ & 284 & 37.3 & 12.2 & 9.44 & 67.9 \\
\hline Avg. summer temperature $\left({ }^{\circ} \mathrm{F}\right)$ & 284 & 73.3 & 5.82 & 60.8 & 89.7 \\
\hline Summer precipitation (inches) & 284 & 11 & 5.06 & 0.44 & 23.3 \\
\hline Transportation score & 284 & 50.4 & 29.2 & 0.00 & 100 \\
\hline Education score & 284 & 51.2 & 29.3 & 0.00 & 100 \\
\hline Arts score & 284 & 51.1 & 29.1 & 0.00 & 100 \\
\hline Healthcare score & 284 & 49.2 & 28.7 & 0.00 & 98.3 \\
\hline Recreation score & 284 & 53.3 & 28.4 & 0.00 & 100 \\
\hline $\begin{array}{l}\text { Annual avg. of sunshine ( } \% \text { of possible } \\
\text { sunshine in } 24 \text { hours) }\end{array}$ & 284 & 60.8 & 8.32 & 43 & 78 \\
\hline
\end{tabular}

${ }^{a} \mathrm{~N}$ denotes the number of MSAs in our dataset for which we have nonmissing observations. 
Table 5. First-Stage Estimates_Location Choice Model for Prime-Aged Movers Broken down by Household Size and Age

Group

\begin{tabular}{|c|c|c|c|c|c|c|}
\hline \multirow[b]{3}{*}{ Variable } & \multicolumn{2}{|c|}{ Model 1} & \multirow{2}{*}{\multicolumn{2}{|c|}{$\begin{array}{c}\text { Model 2 } \\
\text { Include interactions } \\
\text { with household size } \\
\text { dummies }\end{array}$}} & \multicolumn{2}{|c|}{ Model 3} \\
\hline & \multicolumn{2}{|c|}{ No interactions } & & & \multicolumn{2}{|c|}{$\begin{array}{l}\text { Include interactions } \\
\text { with age group } \\
\text { dummies }\end{array}$} \\
\hline & Coefficient & t-Statistic & Coefficient & t-Statistic & Coefficient & t-Statistic \\
\hline Log (household wages) & 1.63 & 35.8 & 1.9 & 32.1 & 2.03 & 38.3 \\
\hline $\begin{array}{l}\text { Log (distance between state of origin and state of } \\
\text { MSA j ) }\end{array}$ & -0.146 & -157 & -0.146 & -158 & -0.146 & -158 \\
\hline $\begin{array}{l}\text { Log (distance between division of origin and division } \\
\text { of MSA } j \text { ) }\end{array}$ & -0.0332 & -31.8 & -0.0331 & -31.7 & -0.0332 & -31.8 \\
\hline $\begin{array}{l}\text { Log (distance between region of origin and region of } \\
\text { MSA j ) }\end{array}$ & -0.0331 & -39.7 & -0.0332 & -39.8 & -0.0331 & -39.6 \\
\hline Log (household wages) $* \mathrm{I}($ hh size $=2)$ & & & -0.0256 & -0.39 & & \\
\hline Log (household wages) $*$ I (hh size $>2)$ & & & -0.611 & -10.3 & & \\
\hline Log (household wages) * I(age group 36 to 45$)$ & & & & & -0.567 & -10.4 \\
\hline Log (household wages) * I(age group 46 to 55$)$ & & & & & -0.98 & -14.8 \\
\hline Number of observations & 115, & 623 & 115, & 623 & 115 & 623 \\
\hline
\end{tabular}


Sinha and Cropper

\begin{tabular}{|c|c|c|c|}
\hline & Model 1 & Model 2 & Model 3 \\
\hline & No interactions & $\begin{array}{c}\text { Include interactions } \\
\text { with household size } \\
\text { dummies }\end{array}$ & $\begin{array}{c}\text { Include interactions } \\
\text { with age group } \\
\text { dummies }\end{array}$ \\
\hline Variable & Coefficient t-Statistic & Coefficient t-Statistic & Coefficient t-Statistic \\
\hline Log likelihood & $-218,028$ & $-217,959$ & $-217,911$ \\
\hline Number of iterations & 62 & 68 & 64 \\
\hline
\end{tabular}

Note: I(.) represents a dummy variable equal to 1 if the condition in parentheses holds. 
Sinha and Cropper

Table 6. Second-Stage Results for Prime-Aged Movers ${ }^{a}$

\begin{tabular}{|c|c|c|c|c|c|c|c|c|}
\hline \multirow{3}{*}{$\begin{array}{c}\text { Using first-stage estimates } \\
\text { from Model } 1 \\
\text { (No. of observations }=\mathbf{2 8 4} \text { ) }\end{array}$} & \multicolumn{2}{|c|}{$\begin{array}{c}\text { Quadratic } \\
\text { specification } \\
\text { Model } 4\end{array}$} & \multicolumn{2}{|c|}{ Log specification } & \multicolumn{2}{|c|}{ Quadratic specification } & \multicolumn{2}{|c|}{ Log specification } \\
\hline & \multicolumn{4}{|c|}{ Include division dummies } & \multicolumn{4}{|c|}{ No division dummies } \\
\hline & Coefficient & Statistic & Coefficient & t-Statistic & Coefficient & (clustered) & Coefficient & (clustered) \\
\hline Mean $\mathrm{PM}_{2.5}$ & -0.032 & -1.97 & -0.00784 & -0.552 & -0.00677 & -0.36 & 0.00401 & 0.26 \\
\hline Violent crime rate & -22.4 & -1.58 & -15.2 & -1.08 & -17.6 & -1.27 & -15.1 & -1.17 \\
\hline Transportation score & -0.00304 & -2.14 & -0.00308 & -2.17 & -0.00267 & -1.04 & -0.00268 & -1.03 \\
\hline Recreation score & 0.00194 & 1.22 & 0.00208 & 1.3 & 0.00449 & 2.75 & 0.00446 & 2.69 \\
\hline Log (population) & 0.882 & 15.7 & 0.843 & 15.4 & 0.759 & 9.49 & 0.743 & 9.13 \\
\hline Distance to coast & -0.748 & -1.02 & -0.735 & -1.00 & -1.20 & -1.71 & -1.22 & -1.74 \\
\hline Distance to coast squared & 0.121 & 0.133 & 0.364 & 0.399 & 1.69 & 2.59 & 1.76 & 2.58 \\
\hline Log (avg. elevation) & 0.0565 & 1.57 & 0.0613 & 1.74 & 0.0546 & 2.00 & 0.0592 & 2.12 \\
\hline Area of parks & 0.0483 & 0.921 & 0.0649 & 1.24 & 0.104 & 1.42 & 0.109 & 1.46 \\
\hline Visibility $>10$ miles & 0.00393 & 1.25 & 0.00484 & 1.59 & 0.00383 & 1.96 & 0.00512 & 2.12 \\
\hline
\end{tabular}


Sinha and Cropper

\begin{tabular}{|c|c|c|c|c|c|c|c|c|}
\hline \multirow{3}{*}{$\begin{array}{c}\text { Using first-stage estimates } \\
\text { from Model } 1 \\
\text { (No. of observations }=284 \text { ) }\end{array}$} & \multicolumn{2}{|c|}{$\begin{array}{c}\text { Quadratic } \\
\text { specification } \\
\text { Model } 4\end{array}$} & \multicolumn{2}{|c|}{ Log specification } & \multicolumn{2}{|c|}{ Quadratic specification } & \multicolumn{2}{|c|}{ Log specification } \\
\hline & \multicolumn{4}{|c|}{ Include division dummies } & \multicolumn{4}{|c|}{ No division dummies } \\
\hline & Coefficient & Statistic & Coefficient & t-Statistic & Coefficient & (clustered) & Coefficient & (clustered) \\
\hline Annual snowfall & -0.00382 & -1.38 & -0.00606 & -2.3 & -0.00721 & -1.78 & -0.00778 & -2.03 \\
\hline July relative humidity & -0.000351 & -0.0674 & -0.00202 & -0.391 & -0.011 & -2.72 & -0.0107 & -2.61 \\
\hline Avg. winter temperature & 0.0707 & 3.36 & & & 0.0595 & 2.89 & & \\
\hline $\begin{array}{l}\text { Avg. summer temperature } \\
\text { squared }\end{array}$ & -0.000987 & -0.874 & & & 0.0000852 & 0.0788 & & \\
\hline Log (summer precipitation) & 0.319 & 3.01 & 0.237 & 2.32 & 0.407 & 3.66 & 0.386 & 3.76 \\
\hline Log (winter temperature) & & & 0.727 & 2.95 & & & 0.727 & 3.75 \\
\hline Log (summer temperature) & & & -2.01 & -1.83 & & & -2.57 & -3.46 \\
\hline Annual sunshine & -0.0067 & -0.891 & -0.00782 & -1.18 & 0.00428 & 0.506 & 0.00217 & 0.302 \\
\hline
\end{tabular}




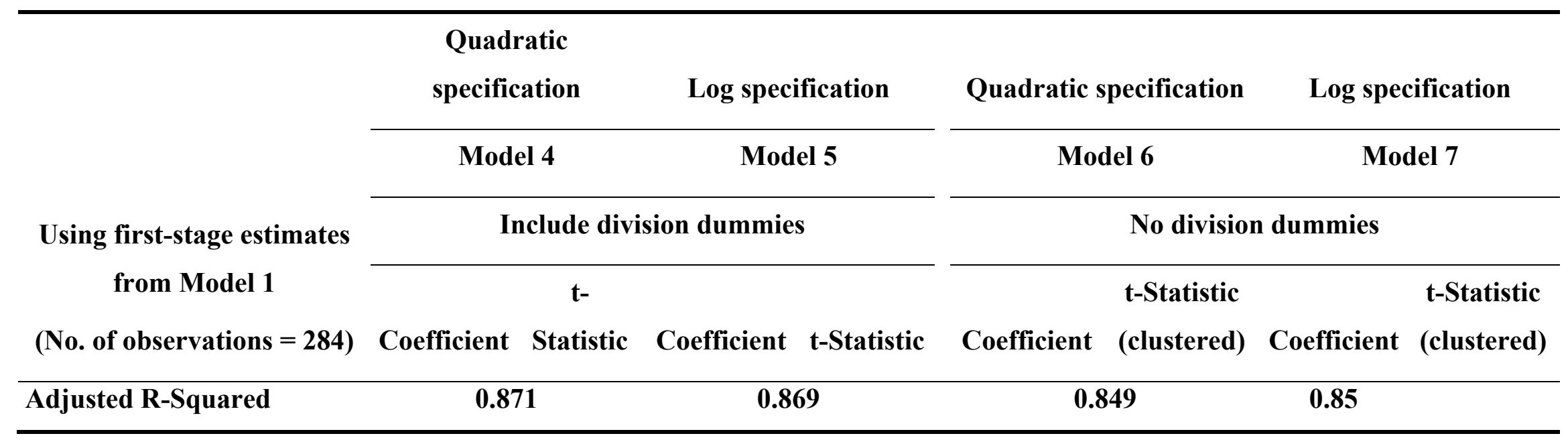

${ }^{a}$ Violent crime rate is the number of crimes per person, distance to the coast is in 1000s of miles, area of parks is in 1000 s of square miles; all other variables are in the same units as Table 4. 
Table 7. Marginal Effects of Climate Variables for Prime-Aged Movers

\begin{tabular}{|c|c|c|c|c|c|c|}
\hline \multirow[b]{4}{*}{ Temperature $\left({ }^{\circ} \mathbf{F}\right)$} & \multirow{2}{*}{\multicolumn{2}{|c|}{$\begin{array}{c}\text { Quadratic specification } \\
\text { Model } 4\end{array}$}} & \multirow{2}{*}{$\begin{array}{c}\text { Log specification } \\
\text { Model } 5\end{array}$} & \multicolumn{2}{|c|}{ Quadratic specification } & \multirow{2}{*}{$\begin{array}{c}\text { Log specification } \\
\text { Model } 7\end{array}$} \\
\hline & & & & \multicolumn{2}{|c|}{ Model 6} & \\
\hline & \multicolumn{3}{|c|}{ Include division dummies } & \multicolumn{3}{|c|}{ No division dummies } \\
\hline & Marginal effect & t-Statistic & Marginal effect & Marginal effect & $\begin{array}{l}\text { t-Statistic } \\
\text { (clustered) }\end{array}$ & Marginal effect \\
\hline \multicolumn{7}{|l|}{ Summer } \\
\hline 60 & 0.0109 & 0.3 & -0.0336 & -0.0357 & -1.38 & -0.0429 \\
\hline 65 & 0.00107 & 0.04 & -0.031 & -0.0348 & -2.12 & -0.0396 \\
\hline 70 & -0.0088 & -0.47 & -0.0288 & -0.034 & -3.32 & -0.0367 \\
\hline 75 & -0.0187 & -1.17 & -0.0269 & -0.0331 & -2.52 & -0.0343 \\
\hline 80 & -0.0285 & -1.4 & -0.0252 & -0.0323 & -1.48 & -0.0322 \\
\hline 85 & -0.0384 & -1.33 & -0.0237 & -0.0314 & -0.99 & -0.0303 \\
\hline 90 & -0.0483 & -1.24 & -0.0224 & -0.0306 & -0.72 & -0.0286 \\
\hline \multicolumn{7}{|l|}{ Winter } \\
\hline 10 & 0.057 & 3.38 & 0.0727 & 0.049 & 3.01 & 0.0727 \\
\hline 15 & 0.0501 & 3.36 & 0.0484 & 0.0437 & 3.09 & 0.0485 \\
\hline 20 & 0.0432 & 3.32 & 0.0363 & 0.0385 & 3.18 & 0.0364 \\
\hline 25 & 0.0363 & 3.2 & 0.0291 & 0.0333 & 3.28 & 0.0291 \\
\hline 30 & 0.0295 & 2.96 & 0.0242 & 0.028 & 3.37 & 0.0242 \\
\hline
\end{tabular}


Sinha and Cropper

\begin{tabular}{|c|c|c|c|c|c|c|}
\hline \multirow[b]{4}{*}{ Temperature $\left({ }^{\circ} \mathbf{F}\right)$} & \multirow{2}{*}{\multicolumn{2}{|c|}{$\begin{array}{c}\text { Quadratic specification } \\
\text { Model } 4\end{array}$}} & \multirow{2}{*}{$\begin{array}{c}\text { Log specification } \\
\text { Model } 5\end{array}$} & \multirow{2}{*}{\multicolumn{2}{|c|}{$\begin{array}{c}\text { Quadratic specification } \\
\text { Model } 6\end{array}$}} & \multirow{2}{*}{$\begin{array}{c}\text { Log specification } \\
\text { Model } 7\end{array}$} \\
\hline & & & & & & \\
\hline & \multicolumn{3}{|c|}{ Include division dummies } & \multicolumn{3}{|c|}{ No division dummies } \\
\hline & Marginal effect & t-Statistic & Marginal effect & Marginal effect & $\begin{array}{l}\text { t-Statistic } \\
\text { (clustered) }\end{array}$ & Marginal effect \\
\hline 35 & 0.0226 & 2.53 & 0.0208 & 0.0228 & 3.37 & 0.0208 \\
\hline 40 & 0.0157 & 1.86 & 0.0182 & 0.0175 & 3.08 & 0.0182 \\
\hline 45 & 0.00883 & 1.03 & 0.0161 & 0.0123 & 2.27 & 0.0162 \\
\hline 50 & 0.00195 & 0.21 & 0.0145 & 0.00705 & 1.17 & 0.0145 \\
\hline 55 & -0.00493 & -0.47 & 0.0132 & 0.00181 & 0.25 & 0.0132 \\
\hline 60 & -0.0118 & -0.98 & 0.0121 & -0.00343 & -0.38 & 0.0121 \\
\hline 65 & -0.0187 & -1.35 & 0.0112 & -0.00867 & -0.8 & 0.0112 \\
\hline
\end{tabular}

Note: Boldface type indicates that marginal effects are statistically significant. The t-statistic does not vary with temperature for the log specifications. 
Sinha and Cropper

Table 8. MWTP for a $1^{\circ} \mathrm{F}$ Change in Temperature as a Percentage of Income for Different Demographic Groups

\begin{tabular}{|c|c|c|c|c|c|c|c|}
\hline \multirow{4}{*}{$\begin{array}{c}\text { Temperature } \\
\left({ }^{\circ} \mathbf{F}\right)\end{array}$} & \multicolumn{2}{|r|}{$\begin{array}{c}\text { Quadratic } \\
\text { specification }\end{array}$} & \multirow{2}{*}{\multicolumn{2}{|c|}{$\begin{array}{c}\text { Quadratic specification } \\
\text { Model } 2\end{array}$}} & \multicolumn{3}{|c|}{ Quadratic specification } \\
\hline & \multicolumn{2}{|c|}{ Model 1} & & & & Model 3 & \\
\hline & & & \multicolumn{2}{|c|}{ Household size } & \multicolumn{3}{|c|}{ Age of household head } \\
\hline & \multicolumn{2}{|c|}{ All prime-aged movers } & $\leq 2$ & $>2$ & 26 to 35 & 36 to 45 & 46 to 55 \\
\hline \multicolumn{8}{|l|}{ Summer } \\
\hline 60 & -2.63 & -2.19 & -1.88 & -2.86 & -1.71 & -2.45 & -3.49 \\
\hline 65 & -2.43 & -2.14 & -1.86 & -2.71 & -1.72 & -2.36 & -3.27 \\
\hline 70 & -2.26 & -2.09 & -1.84 & -2.57 & -1.72 & -2.27 & -3.05 \\
\hline 75 & -2.11 & -2.03 & -1.82 & -2.43 & -1.72 & -2.19 & -2.84 \\
\hline 80 & -1.97 & -1.98 & -1.80 & -2.29 & -1.73 & -2.10 & -2.62 \\
\hline 85 & -1.86 & -1.93 & -1.78 & -2.15 & -1.73 & -2.01 & -2.40 \\
\hline 90 & -1.75 & -1.88 & -1.76 & -2.00 & -1.73 & -1.92 & -2.18 \\
\hline \multicolumn{8}{|l|}{ Winter } \\
\hline 10 & 4.46 & 3.01 & 2.59 & 3.76 & 2.44 & 3.34 & 4.61 \\
\hline 15 & 2.98 & 2.68 & 2.31 & 3.35 & 2.18 & 2.98 & 4.12 \\
\hline 20 & 2.23 & 2.36 & 2.03 & 2.95 & 1.91 & 2.62 & 3.62 \\
\hline 25 & 1.79 & 2.04 & 1.75 & 2.55 & 1.65 & 2.26 & 3.12 \\
\hline 30 & 1.49 & 1.72 & 1.48 & 2.14 & 1.39 & 1.90 & 2.62 \\
\hline
\end{tabular}


Sinha and Cropper

\begin{tabular}{|c|c|c|c|c|c|c|c|}
\hline \multirow{4}{*}{$\begin{array}{c}\text { Temperature } \\
\left({ }^{\circ} \mathbf{F}\right)\end{array}$} & Log specification & $\begin{array}{c}\text { Quadratic } \\
\text { specification }\end{array}$ & \multicolumn{2}{|c|}{ Quadratic specification } & \multicolumn{3}{|c|}{ Quadratic specification } \\
\hline & \multicolumn{2}{|c|}{ Model 1} & \multicolumn{2}{|c|}{ Model 2} & \multicolumn{3}{|c|}{ Model 3} \\
\hline & & & \multicolumn{2}{|c|}{ Household size } & \multicolumn{3}{|c|}{ Age of household head } \\
\hline & \multicolumn{2}{|c|}{ All prime-aged movers } & $\leq 2$ & $>2$ & 26 to 35 & 36 to 45 & 46 to 55 \\
\hline 35 & 1.28 & 1.40 & 1.20 & 1.74 & 1.13 & 1.54 & 2.13 \\
\hline 40 & 1.12 & 1.08 & 0.92 & 1.33 & 0.87 & 1.19 & 1.63 \\
\hline 45 & 0.99 & 0.76 & 0.65 & 0.93 & 0.61 & $\mathbf{0 . 8 3}$ & 1.13 \\
\hline 50 & 0.89 & 0.43 & 0.37 & 0.53 & 0.35 & 0.47 & 0.64 \\
\hline 55 & 0.81 & 0.11 & 0.09 & 0.12 & 0.09 & 0.11 & 0.14 \\
\hline 60 & 0.74 & -0.21 & -0.18 & -0.28 & -0.17 & -0.25 & -0.36 \\
\hline 65 & 0.69 & -0.53 & -0.46 & -0.69 & -0.44 & -0.61 & -0.86 \\
\hline
\end{tabular}

Note: Boldface type indicates that marginal effects in Table 7 are statistically significant. 
Table 9. WTP (As a Percentage of Income) for Temperature Changes in 26 Cities

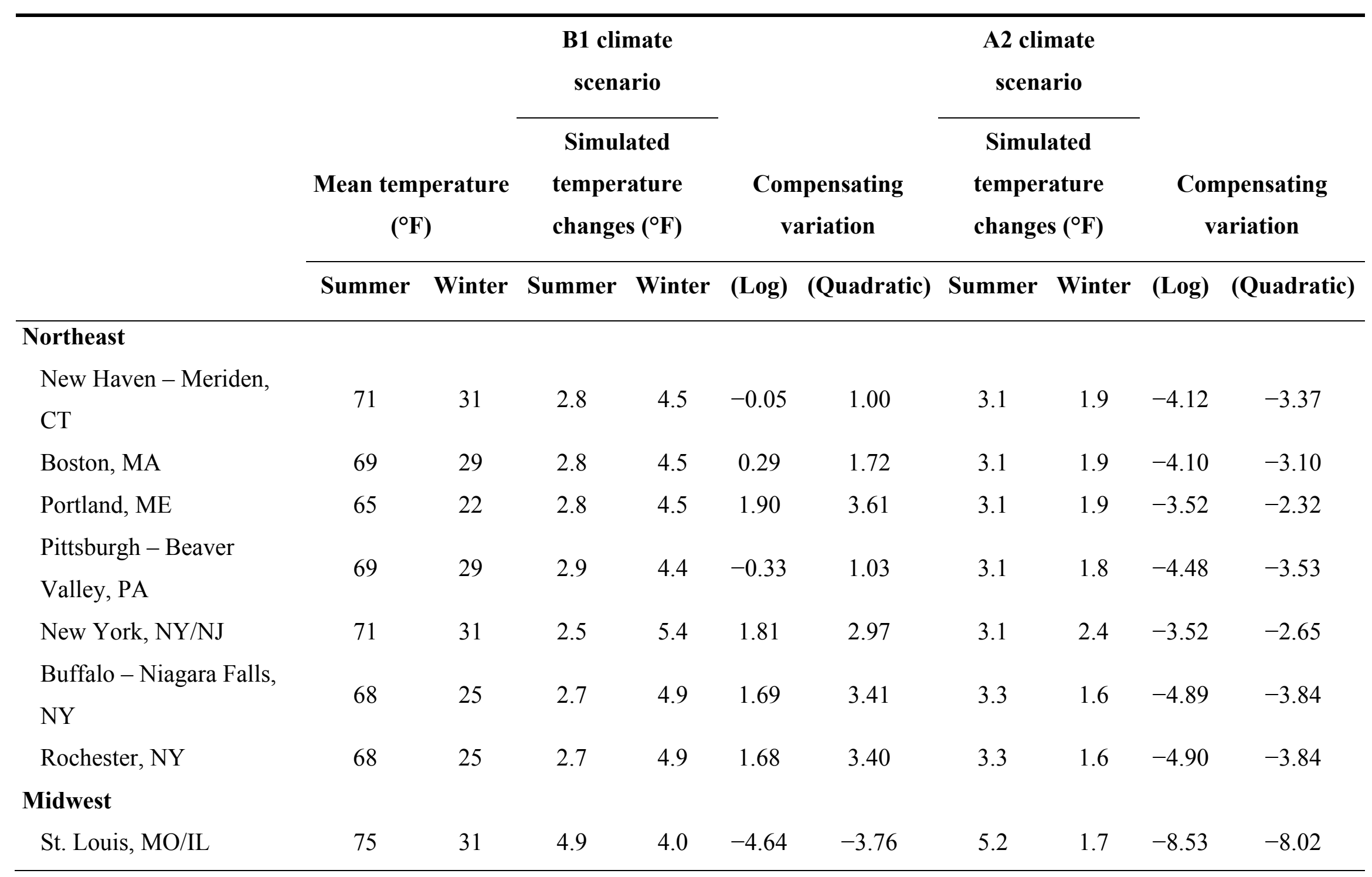


Sinha and Cropper

\begin{tabular}{|c|c|c|c|c|c|c|c|c|c|c|}
\hline & \multicolumn{2}{|c|}{$\begin{array}{c}\text { Mean temperature } \\
\left({ }^{\circ} \mathbf{F}\right)\end{array}$} & \multicolumn{2}{|c|}{$\begin{array}{c}\text { B1 climate } \\
\text { scenario } \\
\text { Simulated } \\
\text { temperature } \\
\text { changes }\left({ }^{\circ} \mathbf{F}\right)\end{array}$} & \multicolumn{6}{|c|}{$\begin{array}{l}\text { A2 climate } \\
\text { scenario }\end{array}$} \\
\hline $\begin{array}{l}\text { Chicago - Gary - Lake, } \\
\text { IL }\end{array}$ & 71 & 25 & 3.0 & 3.1 & -1.38 & -0.24 & 3.4 & 1.9 & -4.18 & -3.28 \\
\hline $\begin{array}{l}\text { Minneapolis - St. Paul, } \\
\text { MN }\end{array}$ & 67 & 14 & 3.0 & 2.9 & 1.62 & 1.47 & 3.3 & 2.5 & -0.31 & -0.37 \\
\hline $\begin{array}{l}\text { West Palm Beach - Boca } \\
\text { Raton - Delray Beach, FL }\end{array}$ & 82 & 67 & 1.4 & 2.1 & -1.33 & -4.35 & 1.7 & 1.9 & -2.05 & -4.83 \\
\hline Orlando, FL & 81 & 60 & 1.5 & 2.2 & -1.26 & -3.64 & 1.8 & 1.9 & -2.07 & -4.06 \\
\hline Raleigh - Durham, NC & 76 & 41 & 3.4 & 3.4 & -3.32 & -3.76 & 3.7 & 2.5 & -5.03 & -5.28 \\
\hline Washington, DC/MD/VA & 74 & 35 & 2.9 & 4.4 & -0.84 & -0.36 & 3.1 & 1.8 & -4.44 & -4.02 \\
\hline Nashville, TN & 76 & 39 & 4.4 & 3.1 & -5.62 & -5.73 & 5.0 & 2.1 & -7.89 & -7.90 \\
\hline Houston - Brazoria, TX & 82 & 54 & 4.9 & 2.8 & -7.12 & -9.72 & 4.4 & 2.5 & -6.34 & -8.58 \\
\hline Dallas - Fort Worth, TX & 82 & 47 & 6.3 & 3.0 & -9.33 & -11.10 & 5.8 & 1.9 & -9.39 & -10.60 \\
\hline
\end{tabular}


Sinha and Cropper

\begin{tabular}{|c|c|c|c|c|c|c|c|c|c|c|}
\hline & & & \multicolumn{2}{|c|}{$\begin{array}{c}\text { B1 climate } \\
\text { scenario } \\
\text { Simulated } \\
\text { temperature } \\
\text { changes }\left({ }^{\circ} \mathbf{F}\right)\end{array}$} & \multicolumn{6}{|c|}{$\begin{array}{l}\text { A2 climate } \\
\text { scenario }\end{array}$} \\
\hline Phoenix, AZ & 88 & 53 & 3.4 & 2.9 & -3.72 & -6.21 & 3.3 & 2.0 & -4.31 & -6.15 \\
\hline Las Vegas, NV & 77 & 40 & 3.7 & 2.3 & -5.02 & -5.20 & 3.4 & 2.0 & -4.70 & -4.84 \\
\hline $\begin{array}{l}\text { Denver - Boulder - } \\
\text { Longmont, CO }\end{array}$ & 65 & 27 & 3.9 & 2.9 & -4.69 & -2.93 & 4.1 & 2.9 & -5.28 & -3.47 \\
\hline Fresno, CA & 74 & 46 & 5.0 & 2.7 & -8.01 & -8.71 & 6.5 & 2.5 & -11.50 & -12.20 \\
\hline $\begin{array}{l}\text { San Francisco - Oakland } \\
\text { - Vallejo, CA }\end{array}$ & 65 & 49 & 0.4 & 1.5 & 0.35 & -0.22 & 1.9 & 1.5 & -3.15 & -3.36 \\
\hline Sacramento, CA & 71 & 42 & 5.0 & 2.7 & -8.35 & -8.26 & 6.5 & 2.5 & -12.00 & -11.80 \\
\hline Seattle - Everett, WA & 61 & 38 & 3.5 & 1.0 & -7.88 & -6.52 & 3.3 & 1.4 & -6.94 & -5.64 \\
\hline $\begin{array}{l}\text { Population-weighted } \\
\text { average }\end{array}$ & 74 & 38 & 3.3 & 3.3 & -2.69 & -2.73 & 3.6 & 2.1 & -4.97 & -5.04 \\
\hline
\end{tabular}


Figure 1. Marginal Effects of Winter Temperature

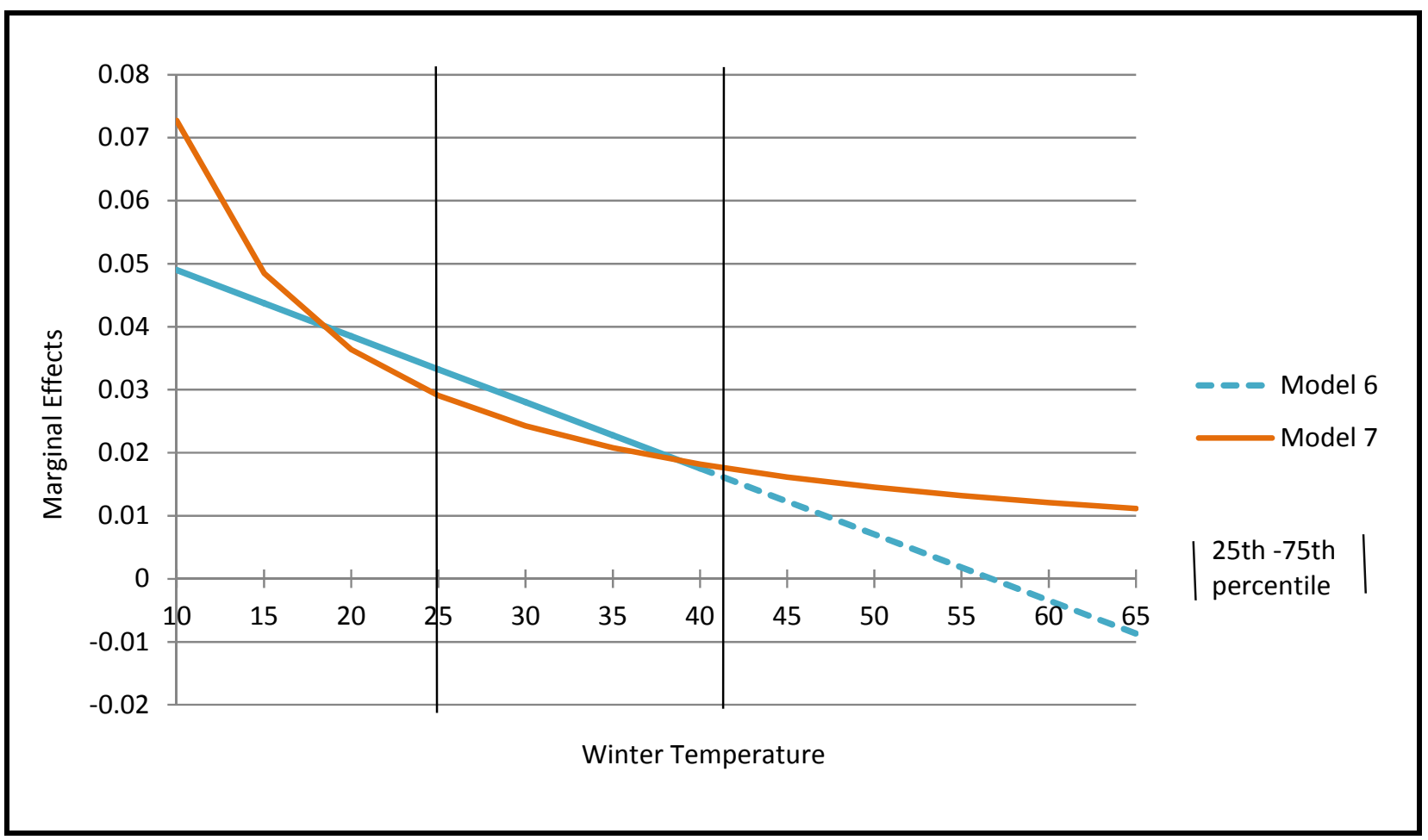

Note: Bold lines indicate that marginal effects in the figure are statistically significant. Vertical lines denote inter-quartile range of temperature. 


\section{Figure 2. Marginal Effects of Summer Temperature}

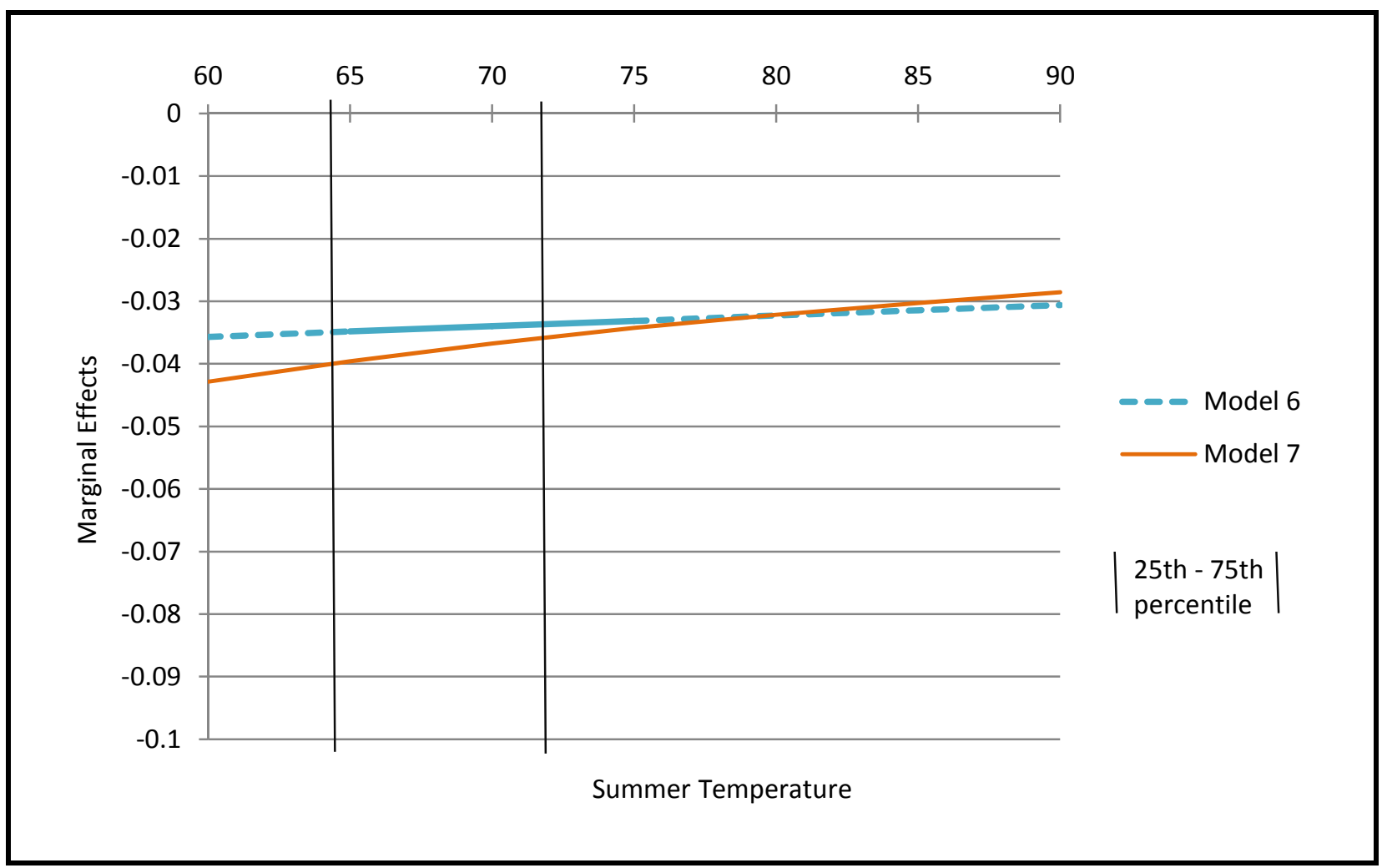

Note: Bold lines indicate that marginal effects in the figure are statistically significant. Vertical lines denote inter-quartile range of temperature. 
Figure 3. Map Showing 26 US Cities and Census Regions

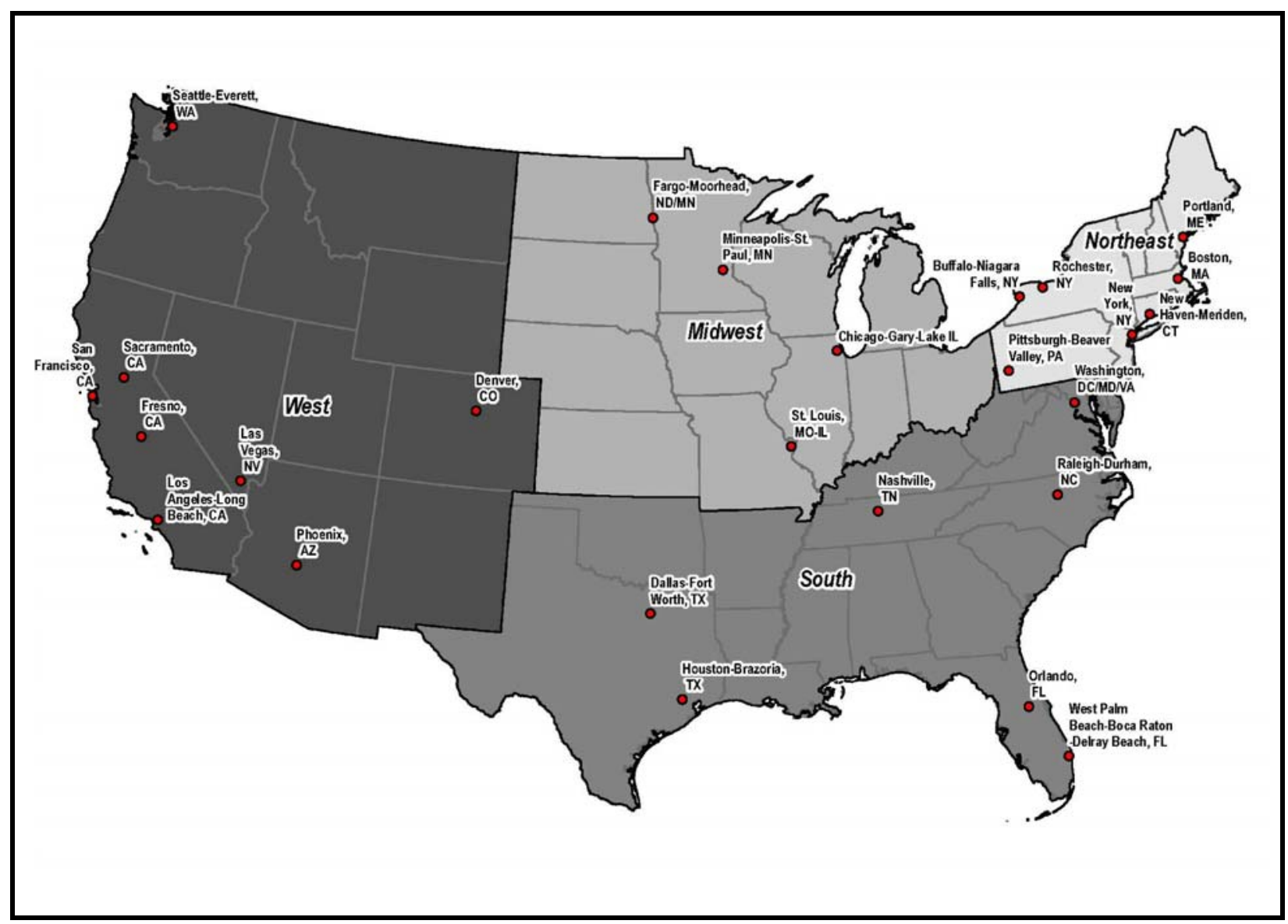




\section{Appendix}

Table A-1. Summary of Hedonic Wage Coefficients

\begin{tabular}{|c|c|c|}
\hline $\begin{array}{c}\text { Variables } \\
\text { (dependent variable: } \log (\text { wage rate) }\end{array}$ & $\begin{array}{l}\text { Mean of estimates } \\
\text { from } 297 \text { MSAs }\end{array}$ & $\begin{array}{l}\text { Std. dev. of estimates } \\
\text { from } 297 \text { MSAs }\end{array}$ \\
\hline $\begin{array}{l}\text { High school (left out category is no high } \\
\text { school) }\end{array}$ & 0.101 & 0.040 \\
\hline Some college & 0.181 & 0.047 \\
\hline College graduate & 0.387 & 0.070 \\
\hline Higher education & 0.553 & 0.076 \\
\hline Age & 0.051 & 0.008 \\
\hline Age squared (divided by 100) & -0.049 & 0.009 \\
\hline Married & 0.095 & 0.022 \\
\hline Male & 0.213 & 0.040 \\
\hline Black (left out category is white) & -0.067 & 0.075 \\
\hline Other race & -0.054 & 0.058 \\
\hline Speaks English well & 0.111 & 0.117 \\
\hline Hispanic & -0.043 & 0.080 \\
\hline $\begin{array}{l}\text { Business operations occupation (left out } \\
\text { category is management occupation) }\end{array}$ & -0.125 & 0.067 \\
\hline Financial specialists occupation & -0.114 & 0.078 \\
\hline Computer and math occupation & -0.002 & 0.090 \\
\hline Engineering occupation & -0.074 & 0.084 \\
\hline $\begin{array}{l}\text { Life, physical, and social sciences } \\
\text { occupation }\end{array}$ & -0.183 & 0.112 \\
\hline Social services occupation & -0.345 & 0.085 \\
\hline Legal occupation & -0.040 & 0.137 \\
\hline Teachers occupation & -0.200 & 0.091 \\
\hline
\end{tabular}




\begin{tabular}{|c|c|c|}
\hline $\begin{array}{c}\text { Variables } \\
\text { (dependent variable: } \log (\text { wage rate) }\end{array}$ & $\begin{array}{l}\text { Mean of estimates } \\
\text { from } 297 \text { MSAs }\end{array}$ & $\begin{array}{l}\text { Std. dev. of estimates } \\
\text { from } 297 \text { MSAs }\end{array}$ \\
\hline Other educational occupation & -0.486 & 0.134 \\
\hline Arts, sports, and media occupation & -0.253 & 0.098 \\
\hline Healthcare practitioners occupation & 0.074 & 0.077 \\
\hline Healthcare support occupation & -0.323 & 0.081 \\
\hline Protective services occupation & -0.237 & 0.106 \\
\hline Food and serving occupation & -0.419 & 0.076 \\
\hline Maintenance occupation & -0.466 & 0.079 \\
\hline Personal care service occupation & -0.413 & 0.112 \\
\hline High-skill sales occupation & -0.135 & 0.068 \\
\hline Low-skill sales occupation & -0.228 & 0.064 \\
\hline Office support occupation & -0.298 & 0.052 \\
\hline Construction trades occupation & -0.239 & 0.094 \\
\hline Extraction workers occupation & -0.261 & 0.292 \\
\hline Maintenance workers occupation & -0.185 & 0.067 \\
\hline Production occupation & -0.310 & 0.085 \\
\hline Transportation occupation & -0.356 & 0.074 \\
\hline $\begin{array}{l}\text { Construction industry (left out category is } \\
\text { mining and utilities) }\end{array}$ & -0.178 & 0.098 \\
\hline Manufacturing industry & -0.118 & 0.108 \\
\hline Wholesale industry & -0.185 & 0.099 \\
\hline Retail industry & -0.342 & 0.098 \\
\hline Transportation industry & -0.093 & 0.110 \\
\hline Information and communications industry & -0.139 & 0.114 \\
\hline Finance industry & -0.173 & 0.107 \\
\hline $\begin{array}{l}\text { Professional and scientific management } \\
\text { services industry }\end{array}$ & -0.223 & 0.106 \\
\hline
\end{tabular}




\begin{tabular}{lcc}
\hline \multicolumn{1}{c}{$\begin{array}{c}\text { Variables } \\
\text { (dependent variable: log(wage rate) }\end{array}$} & $\begin{array}{c}\text { Mean of estimates } \\
\text { from 297 MSAs }\end{array}$ & $\begin{array}{c}\text { Std. dev. of estimates } \\
\text { from 297 MSAs }\end{array}$ \\
\hline $\begin{array}{l}\text { Educational and health social services } \\
\text { industry }\end{array}$ & -0.274 & 0.096 \\
Recreation and food services industry & -0.378 & 0.114 \\
Other services industry & -0.361 & 0.101 \\
Public administration industry & -0.131 & 0.100 \\
\hline
\end{tabular}

${ }^{a}$ Because these two industries have very few observations, we bundled them together as the omitted category. 
Table A-2. Coefficients of the Hedonic Housing Equation ${ }^{a}$

Dependent variable: $\log$ (user costs including insurance and utility costs)

Number of observations used: $\mathbf{3 , 3 4 6 , 5 8 8}$

Adjusted R-Sq: 0.5737

\begin{tabular}{|c|c|c|}
\hline Variables & Coefficient & t-Statistic \\
\hline Intercept & 5.63 & 499 \\
\hline House is owned & 0.505 & 634 \\
\hline $\begin{array}{l}3 \text { Bedrooms (left out category is less than } 3 \\
\text { bedrooms) }\end{array}$ & 0.129 & 100 \\
\hline 4 Bedrooms & 0.154 & 99.4 \\
\hline 5 Bedrooms & 0.284 & 162 \\
\hline Greater than 5 bedrooms & 0.486 & 225 \\
\hline 2 Rooms (left out category is less than 2 rooms) & 0.139 & 69.3 \\
\hline 3 Rooms & 0.14 & 73.7 \\
\hline 4 Rooms & 0.169 & 79.8 \\
\hline 5 Rooms & 0.233 & 104 \\
\hline 6 Rooms & 0.329 & 141 \\
\hline Greater than 6 rooms & 0.533 & 224 \\
\hline Complete kitchen & -0.035 & -9.65 \\
\hline Complete plumbing & 0.218 & 55.9 \\
\hline 1 to 10 Acres & -0.214 & -97.5 \\
\hline $\begin{array}{l}0 \text { to } 1 \text { Years old (left out category is }>61 \text { years } \\
\text { old) }\end{array}$ & 0.39 & 193 \\
\hline 2 to 5 Years old & 0.369 & 292 \\
\hline 6 to 10 Years old & 0.314 & 255 \\
\hline 11 to 20 Years old & 0.216 & 216 \\
\hline 21 to 30 Years old & 0.108 & 113 \\
\hline
\end{tabular}




\section{Dependent variable: log (user costs including insurance and utility costs)}

Number of observations used: $3,346,588$

Adjusted R-Sq: 0.5737

\begin{tabular}{lcc}
\hline \multicolumn{1}{c}{ Variables } & Coefficient & t-Statistic \\
\hline 31 to 40 Years old & 0.058 & 59.2 \\
41 to 50 Years old & 0.02 & 20.8 \\
51 to 60 Years old & -0.025 & -22 \\
Number of units in structure: single-family & & -140 \\
attached (left out category is single-family & -0.157 & -106 \\
detached) & -0.27 & -128 \\
2 Units in structure & -0.326 & -138 \\
3 to 4 Units in structure & -0.353 & -126 \\
5 to 9 Units in structure & -0.33 & -143 \\
10 to 19 Units in structure & -0.382 & -143 \\
20 to 49 Units in structure & -0.367 & \\
$>50$ Units in structure & & \\
\hline
\end{tabular}

${ }^{a}$ This regression also includes city-specific fixed effects (not included in the table). 